Article

\title{
Hydrogen Peroxide Response in Leaves of Poplar (Populus simonii $\times$ Populus nigra) Revealed from Physiological and Proteomic Analyses
}

\author{
Juanjuan $\mathrm{Yu}^{1,2,+} \mathbb{D}$, Xin Jin ${ }^{1,+}{ }^{+}$Xiaomei Sun ${ }^{2}$, Tianxiang Gao ${ }^{2}$, Xiaomei Chen ${ }^{3}$, Yimin She ${ }^{3}$, \\ Tingbo Jiang ${ }^{1}$, Sixue Chen ${ }^{2,4}$ and Shaojun Dai ${ }^{1,2, *}$ \\ 1 Alkali Soil Natural Environmental Science Center, Northeast Forestry University, \\ Key Laboratory of Saline-alkali Vegetation Ecology Restoration, Ministry of Education, \\ Harbin 150040, China; yujuan8186@163.com (J.Y.); JinXin721612@163.com (X.J.); tbjiang@yahoo.com (T.J.) \\ 2 Development Centre of Plant Germplasm Resources, College of Life and Environmental Sciences, \\ Shanghai Normal University, Shanghai 200234, China; meimeixpz@163.com (X.S.); \\ thalia1@163.com (T.G.); schen@ufl.edu (S.C.) \\ 3 Shanghai Center for Plant Stress Biology, Chinese Academy of Sciences, Shanghai 201602, China; \\ chenxm@sibs.ac.cn (X.C.); ymshe@sibs.ac.cn (Y.S.) \\ 4 Department of Biology, Genetics Institute, Plant Molecular and Cellular Program, \\ Interdisciplinary Center for Biotechnology Research, University of Florida, Gainesville, FL 32610, USA \\ * Correspondence: daishaojun@hotmail.com; Tel./Fax: +86-451-8219-2237 \\ + The authors contributed equally to this work.
}

Received: 29 August 2017; Accepted: 26 September 2017; Published: 2 October 2017

\begin{abstract}
Hydrogen peroxide $\left(\mathrm{H}_{2} \mathrm{O}_{2}\right)$ is one of the most abundant reactive oxygen species (ROS), which plays dual roles as a toxic byproduct of cell metabolism and a regulatory signal molecule in plant development and stress response. Populus simonii $\times$ Populus nigra is an important cultivated forest species with resistance to cold, drought, insect and disease, and also a key model plant for forest genetic engineering. In this study, $\mathrm{H}_{2} \mathrm{O}_{2}$ response in $P$. simonii $\times P$. nigra leaves was investigated using physiological and proteomics approaches. The seedlings of 50-day-old P. simonii $\times$ P. nigra under $\mathrm{H}_{2} \mathrm{O}_{2}$ stress exhibited stressful phenotypes, such as increase of in vivo $\mathrm{H}_{2} \mathrm{O}_{2}$ content, decrease of photosynthetic rate, elevated osmolytes, antioxidant accumulation, as well as increased activities of several ROS scavenging enzymes. Besides, $81 \mathrm{H}_{2} \mathrm{O}_{2}$-responsive proteins were identified in the poplar leaves. The diverse abundant patterns of these proteins highlight the $\mathrm{H}_{2} \mathrm{O}_{2}$-responsive pathways in leaves, including 14-3-3 protein and nucleoside diphosphate kinase (NDPK)-mediated signaling, modulation of thylakoid membrane structure, enhancement of various ROS scavenging pathways, decrease of photosynthesis, dynamics of proteins conformation, and changes in carbohydrate and other metabolisms. This study provides valuable information for understanding $\mathrm{H}_{2} \mathrm{O}_{2}$-responsive mechanisms in leaves of $P$. simonii $\times$ P. nigra.
\end{abstract}

Keywords: Populus simonii $\times$ Populus nigra; leaves; $\mathrm{H}_{2} \mathrm{O}_{2}$ stress; proteomics

\section{Introduction}

Various environmental stresses usually affect reactive oxygen species (ROS) homeostasis in plants, leading to the generation of excess ROS, such as singlet oxygen $\left({ }^{1} \mathrm{O}_{2}\right)$, superoxide anion radicals $\left(\mathrm{O}_{2}{ }^{\bullet-}\right)$, hydrogen peroxide $\left(\mathrm{H}_{2} \mathrm{O}_{2}\right)$, and hydroxyl radicals $\left(\mathrm{HO}^{\bullet}\right)$. Among them, $\mathrm{H}_{2} \mathrm{O}_{2}$ is the most abundant ROS in plant cells during photosynthesis, photorespiration, and respiration processes [1]. The relatively stable non-radical $\mathrm{H}_{2} \mathrm{O}_{2}$ can easily penetrate membrane through water channels, functioning as a likely long-distance signaling molecule in plant growth and stress perception [2]. Moreover, $\mathrm{H}_{2} \mathrm{O}_{2}$ has been proven to be a regulator of many physiological processes, such as cell wall modulation, senescence, 
phytoalexin production, photosynthesis, stomatal movement, and cell cycle [3]. Excess $\mathrm{H}_{2} \mathrm{O}_{2}$ has obvious oxidative destruction of diverse molecules (e.g., proteins, nucleic acids, carbohydrates, and unsaturated lipids) in plant cells [4], which disturbs cellular activity and causes programmed cell death [2]. Interestingly, considerable investigations have shown that low concentration of $\mathrm{H}_{2} \mathrm{O}_{2}$ can improve seed germination [5] and plant resistance to various abiotic and biotic stresses, such as salinity [6,7], osmotic stress [8], aluminum [9], heat [6], chilling [10], paraquat [11], and potato virus $Y$ infection [12]. $\mathrm{H}_{2} \mathrm{O}_{2}$ changes in cells showed as a bell-shaped response with an optimum, depending on the plant species, developmental stages, cell types, and environmental conditions [2,7].

Previous transcriptomic analyses have reported a large number of $\mathrm{H}_{2} \mathrm{O}_{2}$-responsive genes in various plants. For example, more than 170 non-redundant expressed sequence tags (ESTs) in Arabidopsis [13], 713 ESTs in catalase (CAT)-deficient tobacco plants [14], and 437 transcripts in CAT-deficient Arabidopsis [15] were identified as $\mathrm{H}_{2} \mathrm{O}_{2}$ responsive genes. In addition, 6156, 6875 and 3276 transcripts were differentially expressed in three wheat lines including a powdery mildew resistant (PmA) line and two susceptible (Han and Cha) lines [16]. Recently, more than $385 \mathrm{H}_{2} \mathrm{O}_{2}$-responsive proteins were identified in leaves from rice (Oryza sativa L. cv. 93-11) [17], citrus (Citrus aurantium L.) [18], Brachypodium distachyon [19], and wheat (Triticum aestivum L.) [20] using two-dimensional gel electrophoresis (2DE)-based or isobaric tags for relative and absolute quantification (iTRAQ)-based proteomics approaches. The dynamic abundance patterns of these proteins imply that ROS homeostasis, signaling, photosynthesis, energy metabolism, lipid metabolism, and protein turnover play important roles in leaf $\mathrm{H}_{2} \mathrm{O}_{2}$ response. However, most of these proteomics studies focused on model plants and crops. Proteomic analysis of the response of forest trees to $\mathrm{H}_{2} \mathrm{O}_{2}$ stress has not been reported.

Poplar trees are widely planted, and poplar woods are commonly used for building materials, furniture and paper [21]. With the sequencing of Populus genome, poplar has emerged as a model system for molecular and genetic studies of forest trees [21]. Populus simonii $\times$ Populus nigra, also called as Populus xiaohei, is the hybrid of Populus simonii and Populus nigra, which widely distributes in northern China, and has been well used for afforestation and commercial forest. P. simonii $\times$ $P$. nigra is a fast-growing tree species with excellent properties of resistance to cold, drought, insect and disease. The early studies of $P$. simonii $\times P$. nigra were mainly focused on cultivation and germplasm introduction [22]. Recently, research has been focused on using transgenic technology to improve salt and drought tolerance [23], insect resistance [24], and disease resistance [25]. Besides, transcriptics and proteomics have been utilized to study P. simonii $\times$ P. nigra [26-29]. Thousands of genes were shown to be differentially expressed in response to $\mathrm{NaCl}$ stress using cDNA-amplified fragment length polymorphism approach [26] and Solexa/illumine digital gene expression technique [27]. Additionally, genome-wide and proteomic analysis of a TaLEA (Tamarix androssowii late embryogenesis abundant gene)-introduced transgenic P. simonii $\times$ P. nigra dwarf mutant showed 537 genes and 99 proteins were significantly altered, respectively [28,29]. However, there is still lack of proteomics information of $P$. simonii $\times$ P. nigra in response to stresses. Thus, the dynamic proteomic analysis of $P$. simonii $\times$ P. nigra under $\mathrm{H}_{2} \mathrm{O}_{2}$ stress is important for further investigation of the molecular mechanism of oxidative stress and biotechnological manipulation with the aim of enhancing poplar stress tolerance.

In this study, we performed physiological and proteomic analyses of $P$. simonii $\times$ P. nigra leaves under $0,12,24$ and $36 \mathrm{mM} \mathrm{H}_{2} \mathrm{O}_{2}$ treatments for $6 \mathrm{~h}$. Our results indicate that modulation of thylakoid structure, ROS scavenging pathways, photosynthesis, and protein conformation play critical roles in $P$. simonii $\times$ P. nigra leaves in response to $\mathrm{H}_{2} \mathrm{O}_{2}$. These results provide new insights into the molecular mechanisms underlying poplar response to $\mathrm{H}_{2} \mathrm{O}_{2}$ stress.

\section{Results}

\subsection{Photosynthesis under Hydrogen Peroxide $\left(\mathrm{H}_{2} \mathrm{O}_{2}\right)$ Stress}

The leaves of $P$. simonii $\times$ P. nigra were immersed in $0,12,24$ and $36 \mathrm{mM} \mathrm{H}_{2} \mathrm{O}_{2}$ solutions for $6 \mathrm{~h}$, respectively (Figure 1). The photosynthetic parameters were measured to evaluate the photosynthetic 
changes in response to the $\mathrm{H}_{2} \mathrm{O}_{2}$ stress. The net photosynthetic rate (Pn) decreased from $4 \mu \mathrm{mol}$ $\mathrm{CO}_{2} \cdot \mathrm{m}^{-2} \cdot \mathrm{s}^{-1}$ in control to about $3.7 \mu \mathrm{mol} \mathrm{CO} \mathrm{CO}_{2} \cdot \mathrm{m}^{-2} \cdot \mathrm{s}^{-1}$ under each $\mathrm{H}_{2} \mathrm{O}_{2}$ treatment (Figure $2 \mathrm{~A}$ ). The stomatal conductances (Gs) under 12, 24, and $36 \mathrm{mM} \mathrm{H}_{2} \mathrm{O}_{2}$ were also reduced 1.2-, 1.7-, and 2.4-fold, respectively, when compared with control (Figure $2 \mathrm{~B}$ ). In addition, the intercellular $\mathrm{CO}_{2}$ concentration (Ci) increased slightly from $473.2 \mu \mathrm{mol} \mathrm{CO} \cdot \mathrm{mol}^{-1}$ in control to $496.3 \mu \mathrm{mol} \mathrm{CO} 2 \cdot \mathrm{mol}^{-1}$ under $36 \mathrm{mM}$ $\mathrm{H}_{2} \mathrm{O}_{2}$, but the transpiration rate (Tr) was not significantly altered under the $\mathrm{H}_{2} \mathrm{O}_{2}$ stress (Figure $2 \mathrm{C}, \mathrm{D}$ ).

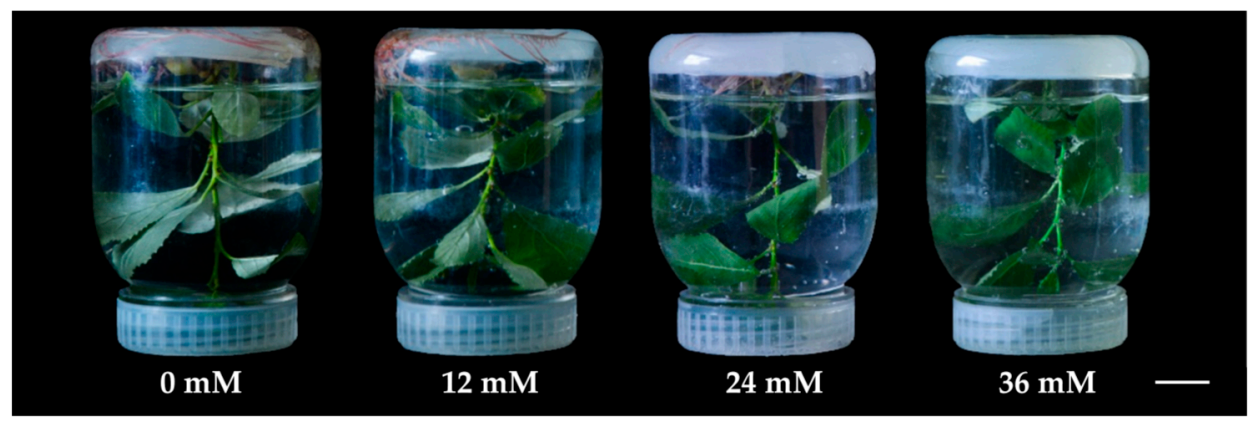

Figure 1. The morphology changes of Populus simonii $\times$ Populus nigra under hydrogen peroxide $\left(\mathrm{H}_{2} \mathrm{O}_{2}\right)$ stress. The aerial portion of 50-day-old seedling of $P$. simonii $\times$ P. nigra was immersed in $0,12,24$ and $36 \mathrm{mM} \mathrm{H}_{2} \mathrm{O}_{2}$ for $6 \mathrm{~h}$, respectively. Bar $=0.2 \mathrm{~cm}$.
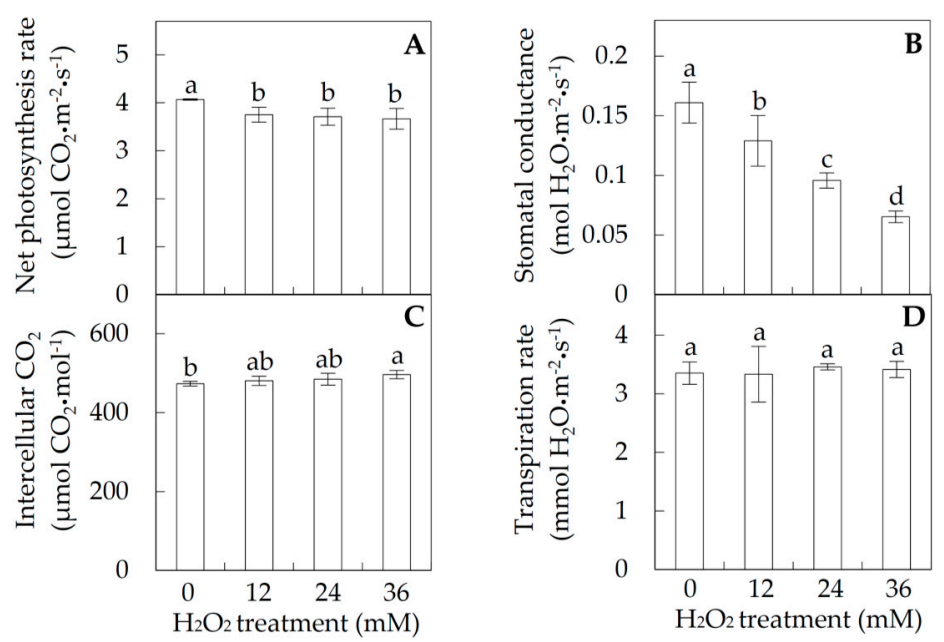

Figure 2. Photosynthetic characteristics of Populus simonii $\times$ Populus nigra leaves under $\mathrm{H}_{2} \mathrm{O}_{2}$ treatment: (A) photosynthesis rate (Pn); (B) stomata conductance (Gs); (C) intercellular $\mathrm{CO}_{2}(\mathrm{Ci})$; and (D) transpiration rate ( $\mathrm{Tr})$. The values were determined after plants were treated with 0,12, 24 and $36 \mathrm{mM} \mathrm{H}_{2} \mathrm{O}_{2}$, and were presented as means \pm standard deviation (SD) $(n=3)$. The different small letters indicate significant difference $(p<0.05)$ among different treatments.

\subsection{Membrane Integrity and Osmolyte Accumulation in Leaves}

To evaluate the effects of $\mathrm{H}_{2} \mathrm{O}_{2}$ on membrane stability, the malondialdehyde (MDA) content and relative electrolyte leakage (REL) in leaves were determined. MDA contents and RELs were not changed under $12 \mathrm{mM} \mathrm{H}_{2} \mathrm{O}_{2}$, but increased under 24 and $36 \mathrm{mM} \mathrm{H}_{2} \mathrm{O}_{2}$ (Figure 3A,B). MDA contents were increased from $17.6 \mathrm{nmol} \cdot \mathrm{g}^{-1}$ fresh weight $(\mathrm{FW})$ in control to about $21.4 \mathrm{nmol} \cdot \mathrm{g}^{-1} \mathrm{FW}$ under 24 and $36 \mathrm{mM} \mathrm{H}_{2} \mathrm{O}_{2}$ (Figure 3A). For REL, a 1.3-fold increase under $24 \mathrm{mM} \mathrm{H}_{2} \mathrm{O}_{2}$ and a 1.9-fold under $36 \mathrm{mM} \mathrm{H}_{2} \mathrm{O}_{2}$ were observed when compared with control (Figure 3B). 

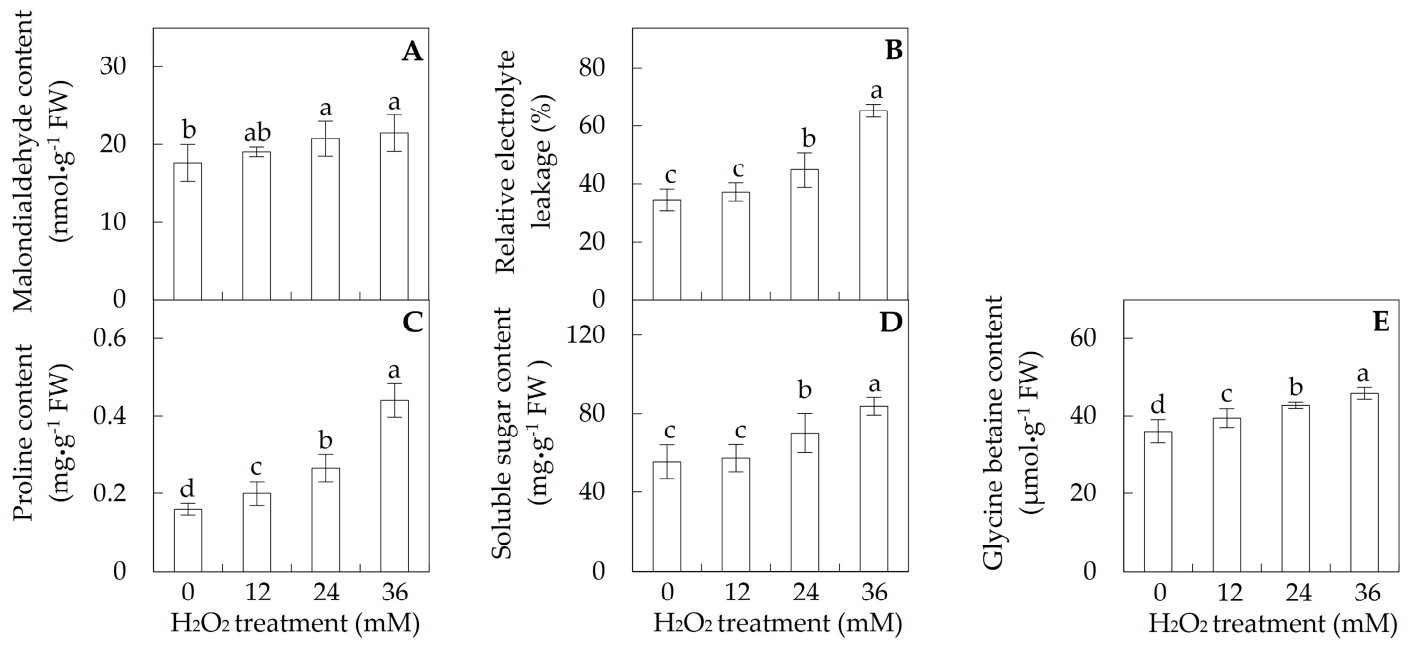

Figure 3. Membrane integrity and osmolyte accumulation in Populus simonii $\times$ Populus nigra leaves under $\mathrm{H}_{2} \mathrm{O}_{2}$ treatment: (A) malondialdehyde content; (B) relative electrolyte leakage; (C) proline content; (D) soluble sugar content; and (E) glycine betanine content. The values were determined after the plants were treated with $0,12,24$ and $36 \mathrm{mM} \mathrm{H}_{2} \mathrm{O}_{2}$, and were presented as means $\pm \mathrm{SD}(n=3)$. The different small letters indicate significant difference $(p<0.05)$ among different treatments.

In addition, the contents of proline and glycine betaine were increased gradually and significantly with the increasing concentration of $\mathrm{H}_{2} \mathrm{O}_{2}$. The proline contents under $\mathrm{H}_{2} \mathrm{O}_{2}$ treatment of 12,24 and $36 \mathrm{mM}$ were increased 1.3-, 1.7-, and 2.8-fold, respectively (Figure 3C). The contents of glycine betaine under three $\mathrm{H}_{2} \mathrm{O}_{2}$ treatments were increased 1.1-, 1.2-, 1.3-fold, respectively (Figure 3E). In addition, the contents of soluble sugar were increased 1.3-fold under $24 \mathrm{mM}$ and 1.5-fold under $36 \mathrm{mM} \mathrm{H}_{2} \mathrm{O}_{2}$ (Figure 3D).

\subsection{ROS and Antioxidant Substances Content, and Antioxidant Enzyme Activities}

To evaluate the ROS homeostasis in the $\mathrm{H}_{2} \mathrm{O}_{2}$-treated leaves, the $\mathrm{O}_{2}{ }^{\bullet-}$ generation rate, $\mathrm{H}_{2} \mathrm{O}_{2}$ content, and the activities of several ROS scavenging enzymes were analyzed. The $\mathrm{O}_{2}{ }^{\bullet-}$ generation rate remained constant under 12 and $36 \mathrm{mM} \mathrm{H}_{2} \mathrm{O}_{2}$ treatments, but was increased 1.2-fold under $24 \mathrm{mM} \mathrm{H}_{2} \mathrm{O}_{2}$ treatment (Figure $4 \mathrm{~A}$ ). $\mathrm{H}_{2} \mathrm{O}_{2}$ content in leaves was increased 1.4-fold under $24 \mathrm{mM} \mathrm{H}_{2} \mathrm{O}_{2}$ treatment (Figure 4A). Superoxide dismutase (SOD) activity was increased about 1.2-fold under 24 and $36 \mathrm{mM} \mathrm{H}_{2} \mathrm{O}_{2}$ treatments (Figure 4B). Besides, the activities of several ROS scavenging enzymes were altered in leaves under certain $\mathrm{H}_{2} \mathrm{O}_{2}$ concentrations. The CAT activities were decreased 1.2-fold under $24 \mathrm{mM}$ and 1.5-fold under $36 \mathrm{mM} \mathrm{H}_{2} \mathrm{O}_{2}$ treatments (Figure $4 \mathrm{~B}$ ). However, the activities of ascorbate peroxidase (APX) were increased about 1.2-fold under 12 and $24 \mathrm{mM} \mathrm{H}_{2} \mathrm{O}_{2}$, and peroxidase (POD) activity was increased 1.7-fold under $24 \mathrm{mM} \mathrm{H}_{2} \mathrm{O}_{2}$ (Figure 4C). The glutathione peroxidase (GPX) activity was increased 1.1-fold under $36 \mathrm{mM} \mathrm{H}_{2} \mathrm{O}_{2}$ treatment (Figure 4D). Moreover, the activities of three enzymes involved in the regeneration of the reduced antioxidants were all altered under the $\mathrm{H}_{2} \mathrm{O}_{2}$ stress. The activity of monodehydroascorbate reductase (MDHAR) was inhibited, while the activities of dehydroascorbate reductase (DHAR) and glutathione reductase (GR) were significantly increased under $\mathrm{H}_{2} \mathrm{O}_{2}$ treatments (Figure 4E,F). The activities of MDHAR under three $\mathrm{H}_{2} \mathrm{O}_{2}$ treatments were reduced 1.1-, 1.2-, and 1.3-fold, respectively. DHAR activities were increased about 1.2-fold under 24 and $36 \mathrm{mM} \mathrm{H}_{2} \mathrm{O}_{2}$, and GR activities were increased 1.3-fold under $24 \mathrm{mM} \mathrm{H}_{2} \mathrm{O}_{2}$ and 1.9-fold under $36 \mathrm{mM} \mathrm{H}_{2} \mathrm{O}_{2}$ (Figure 4E,F). In addition, the glutathione $S$-transferase (GST) activity was induced 1.2-fold under $36 \mathrm{mM} \mathrm{H}_{2} \mathrm{O}_{2}$ treatment (Figure $4 \mathrm{~F}$ ). 

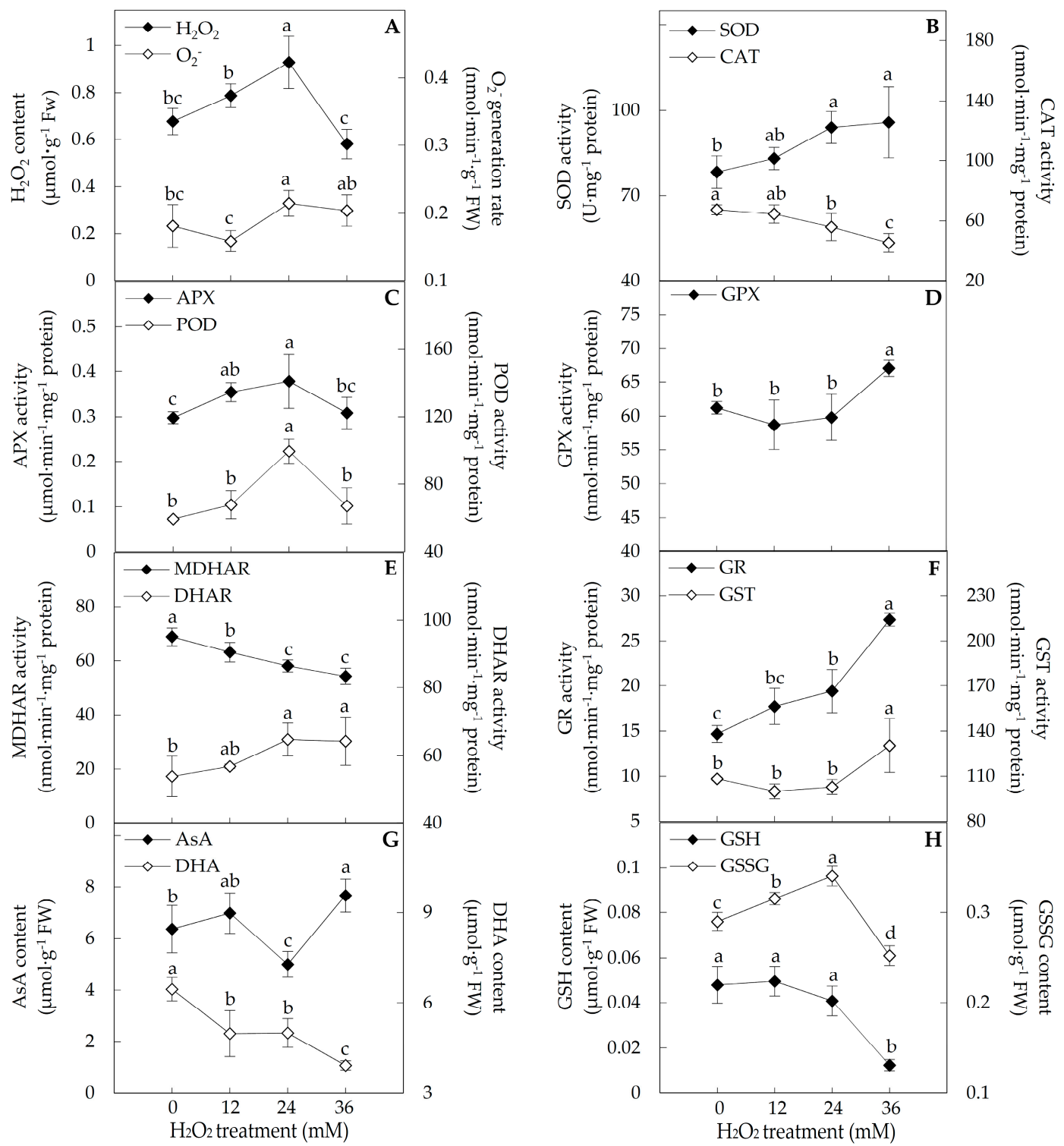

Figure 4. Activities of antioxidant enzymes and antioxidant contents in Populus simonii $\times$ Populus nigra leaves under $\mathrm{H}_{2} \mathrm{O}_{2}$ treatment: (A) $\mathrm{H}_{2} \mathrm{O}_{2}$ content and $\mathrm{O}_{2}{ }^{\bullet-}$ generation rate; (B) activities of superoxide dismutase (SOD) and catalase (CAT); (C) activities of ascorbate peroxidase (APX) and peroxidase (POD); (D) glutathione peroxidase (GPX) activity; (E) activities of monodehydroascorbate reductase (MDHAR) and dehydroascorbate reductase (DHAR); (F) activities of glutathione reductase (GR) and glutathione S-transferase (GST); (G) contents of ascorbate (AsA) and dehydroascorbate (DHA); and (H) contents of reduced glutathione (GSH) content and oxidized glutathione (GSSG) content. The values were determined after plants were treated with $0,12,24$ and $36 \mathrm{mM} \mathrm{H}_{2} \mathrm{O}_{2}$, and were presented as means $\pm \mathrm{SD}(n=3)$. The different small letters indicate significant difference $(p<0.05)$ among different treatments.

In addition, ascorbate (AsA), dehydroascorbate (DHA), reduced glutathione (GSH), and oxidized glutathione (GSSG) were detected in leaves in response to the $\mathrm{H}_{2} \mathrm{O}_{2}$ treatment. The contents of AsA were decreased 1.3-fold under $24 \mathrm{mM} \mathrm{H}_{2} \mathrm{O}_{2}$, but increased 1.2-fold under $36 \mathrm{mM} \mathrm{H}_{2} \mathrm{O}_{2}$ treatment (Figure 4G). The contents of DHA and GSH were all reduced under $\mathrm{H}_{2} \mathrm{O}_{2}$ treatment. DHA contents were decreased about 1.3-fold under 12 and $24 \mathrm{mM} \mathrm{H}_{2} \mathrm{O}_{2}$, and 1.6-fold under $36 \mathrm{mM} \mathrm{H}_{2} \mathrm{O}_{2}$ (Figure 4G). GSH contents were decreased significantly with 3.9-fold under $36 \mathrm{mM} \mathrm{H}_{2} \mathrm{O}_{2}$ (Figure $4 \mathrm{H}$ ). The contents 
of GSSG were increased 1.1-fold under $12 \mathrm{mM} \mathrm{H}_{2} \mathrm{O}_{2}$ and 1.2-fold under $24 \mathrm{mM} \mathrm{H}_{2} \mathrm{O}_{2}$, but decreased 1.2-fold under $36 \mathrm{mM} \mathrm{H}_{2} \mathrm{O}_{2}$ treatment (Figure $4 \mathrm{H}$ ).

\subsection{Identification of $\mathrm{H}_{2} \mathrm{O}_{2}$-Responsive Proteins in Leaves}

To explore the differential accumulated proteins (DAP) in P. simonii $\times$ P. nigra leaves in response to $\mathrm{H}_{2} \mathrm{O}_{2}$, the protein profiles in $0,12,24$ and $36 \mathrm{mM} \mathrm{H}_{2} \mathrm{O}_{2}$-treated leaves were obtained using 2DE. On Coomassie Brilliant Blue (CBB)-stained gels $(24 \mathrm{~cm}, \mathrm{pH} 4-7$ linear gradient immobilized $\mathrm{pH}$ gradient strips), $877 \pm 21,838 \pm 23,768 \pm 48$, and $811 \pm 31$ protein spots from $0,12,24$ and $36 \mathrm{mM} \mathrm{H}_{2} \mathrm{O}_{2}$-treated leaves were detected, respectively (Figure 5 and Figure S1). Among them, 114 protein spots showed differential abundances in leaves under four distinct $\mathrm{H}_{2} \mathrm{O}_{2}$ concentrations (fold change $>1.5$ and $p<0.05)$. All of the 114 DAP spots were subjected to in-gel digestion and protein identification using tandem mass spectrometry. A total of 83 DAPs were identified using matrix-assisted laser desorption/ ionization (MALDI) tandem time of flight (TOF-TOF) mass spectrometry (MS) and Mascot Searching with stringent criteria. Among the 83 identified DAP spots, 81 DAP spots contained a single protein each (Table 1 and Table S1), and the remaining two DAP spots contained more than one protein each (Table S2). Thus, the 81 DAPs were taken as $\mathrm{H}_{2} \mathrm{O}_{2}$-responsive proteins in leaves of $P$. simonii $\times$ P. nigra.

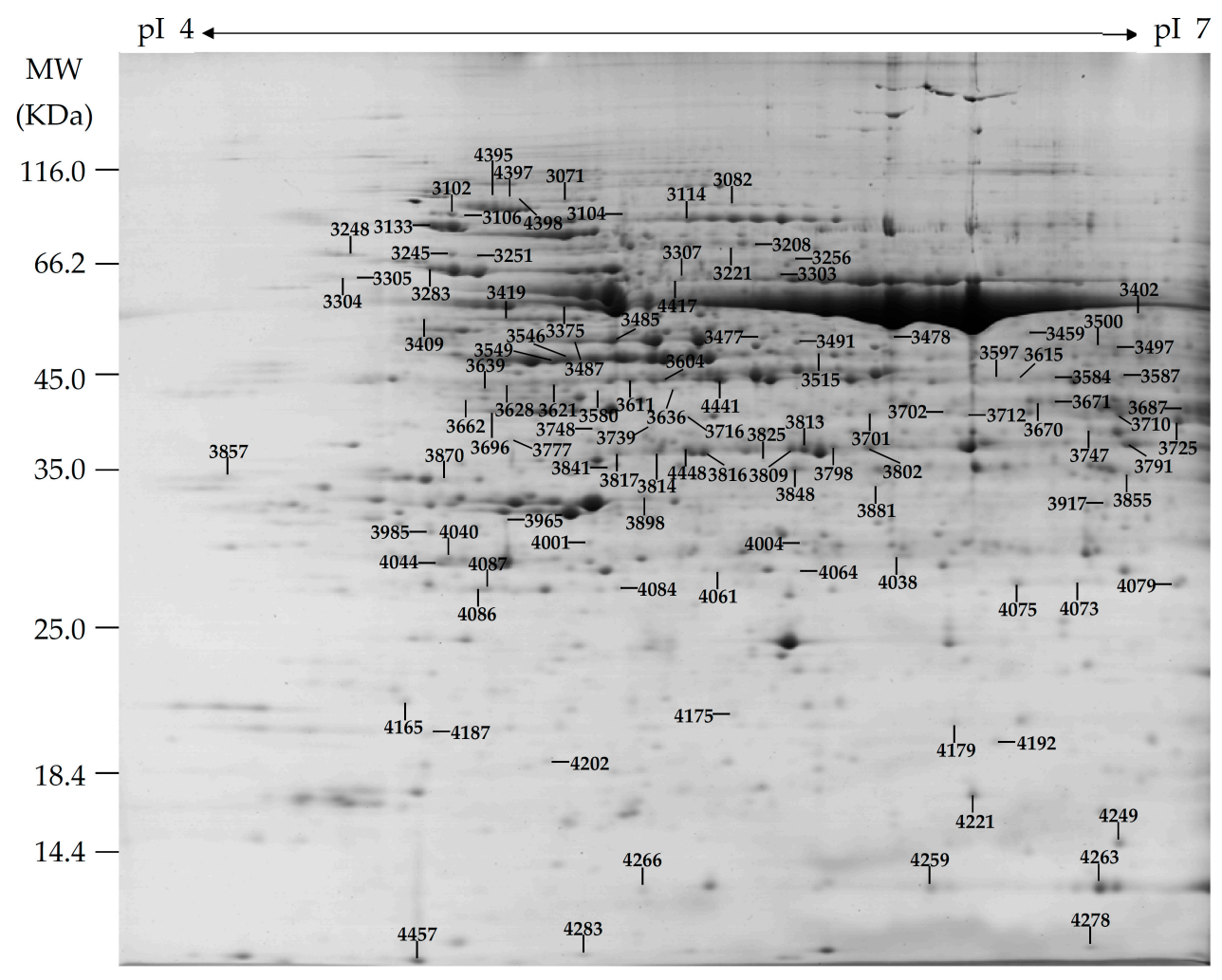

Figure 5. A representative 2DE gel images of proteins from leaves of Populus simonii $\times$ Populus nigra. Proteins were separated on $24 \mathrm{~cm}$ linear gradient immobilized $\mathrm{pH}$ gradient (IPG) strips ( $\mathrm{pH} 4-7$ ) using isoelectric focusing (IEF) in the first dimension, followed by $12.5 \%$ sodium dodecyl sulfate polyacrylamide gel electrophoresis (SDS-PAGE) gels in the second dimension. The 2DE gel was stained with Coomassie Brilliant Blue. Molecular weight (MW) in kilodaltons (KDa) and isoelectric point (pI) of proteins are indicated on the left and top of the gel, respectively. Eighty-one $\mathrm{H}_{2} \mathrm{O}_{2}$-responsive proteins identified by matrix-assisted laser desorption/ ionization (MALDI) tandem time of flight (TOF-TOF) mass spectrometry were marked with numbers on the gel, and the detailed information can be found in Table 1, Figure S1 and Table S1. 
Table 1. $\mathrm{H}_{2} \mathrm{O}_{2}$-responsive proteins in leaves of Populus simonii $\times$ Populus nigra.

\begin{tabular}{|c|c|c|c|c|c|c|c|}
\hline $\begin{array}{l}\text { Spot } \\
\text { No. }{ }^{(a)}\end{array}$ & Protein Name $^{(b)}$ & Abbreviation & $\begin{array}{l}\text { Subcellular } \\
\text { Location }^{(c)}\end{array}$ & $\begin{array}{l}\text { Accession } \\
\text { No. }{ }^{(d)}\end{array}$ & Sco ${ }^{(e)}$ & $\mathbf{Q M}^{(f)}$ & $\begin{array}{c}\mathrm{V} \% \pm \mathrm{SD}^{(g)} \\
0122436\end{array}$ \\
\hline \multicolumn{8}{|c|}{ Photosynthetic electron transfer chain (9) } \\
\hline 4044 & Chlorophyll A/B binding protein & $\mathrm{CAB}$ & Chl & AAA18529 & 135 & 2 & \\
\hline 3965 & Chlorophyll A/B binding protein & $\mathrm{CAB}$ & $\mathrm{Chl}$ & AAA18529 & 153 & 2 & \\
\hline 4040 & $\begin{array}{l}\text { Light harvesting chlorophyll A/B } \\
\text { binding protein }\end{array}$ & $\mathrm{CAB}$ & Chl & ABW70800 & 213 & 3 & \\
\hline 4079 & $\begin{array}{l}\text { Chlorophyll A-B binding } \\
\text { family protein* }\end{array}$ & CAB & Chl & ABK96765 & 201 & 3 & \\
\hline 4064 & $\begin{array}{l}\text { Photosystem II oxygen-evolving } \\
\text { complex protein } 2 \text { precursor }\end{array}$ & OEC2 & Chl & XP_002300858 & 136 & 2 & \\
\hline 4192 & $\begin{array}{l}\text { Photosynthetic NDH subunit of } \\
\text { luminal location } 5 \text {, chloroplastic }\end{array}$ & PnsL5 & Chl & CDP13378 & 102 & 2 & \\
\hline 3848 & $\begin{array}{l}\text { Ferredoxin-NADP reductase, } \\
\text { chloroplastic* }\end{array}$ & FNR & Chl & OAY57547 & 310 & 5 & \\
\hline 3375 & $\begin{array}{l}\text { ATP synthase CF1 } \alpha \text { subunit, } \\
\text { chloroplastic }\end{array}$ & cATP synthase $\alpha$ & Chl & AKF33906 & 369 & 6 & \\
\hline 3104 & $\begin{array}{l}\text { ATP synthase CF1 } \alpha \text { subunit, } \\
\text { chloroplastic }\end{array}$ & cATP synthase $\alpha$ & Chl & AKF33906 & 164 & 2 & \\
\hline \multicolumn{8}{|c|}{ Calvin cycle (28) } \\
\hline 4038 & Carbonic anhydrase isoform $1^{*}$ & CA1 & Chl & ABK96336 & 187 & 3 & \\
\hline 3549 & $\begin{array}{l}\text { Ribulose-bisphosphate carboxylase } \\
\text { (RuBisCO) activase, chloroplastic }\end{array}$ & RCA & $\mathrm{Chl}$ & Q01587 & 316 & 4 & \\
\hline 4441 & RuBisCO activase 1 , chloroplastic & RCA1 & Chl & Q7X9A0 & 162 & 2 & \\
\hline 3485 & $\begin{array}{l}\text { RuBisCO activase, chloroplastic } \\
\text { isoform X1* }\end{array}$ & RCA X1 & $\mathrm{Chl}$ & ABK96359 & 543 & 6 & \\
\hline 3487 & $\begin{array}{l}\text { RuBisCO activase, chloroplastic } \\
\text { isoform } X 1^{*}\end{array}$ & RCA X1 & $\mathrm{Chl}$ & ABK96359 & 401 & 6 & \\
\hline 3477 & Rubisco activase isoform $2^{*}$ & RCA2 & $\mathrm{Chl}$ & CDP00127 & 294 & 5 & \\
\hline 4075 & $\begin{array}{l}\text { RuBisCO activase, chloroplastic } \\
\text { isoform X2 }\end{array}$ & RCA X2 & Chl & XP_011002635 & 294 & 5 & \\
\hline 3777 & RuBisCO large chain & RBCL & $\mathrm{Chl}$ & O78258 & 176 & 2 & \\
\hline 3303 & RuBisCO large subunit & RBCL & Chl & CUR00003 & 176 & 2 & \\
\hline 3497 & RuBisCO large chain & RBCL & $\mathrm{Chl}$ & O78258 & 108 & 2 & \\
\hline 4259 & RuBisCO small chain & RBCS & Chl & XP_011035062 & 243 & 6 & \\
\hline 4263 & RuBisCO small chain & RBCS & Chl & XP_002531624 & 112 & 2 & \\
\hline 3584 & $\begin{array}{l}\text { Phosphoglycerate kinase } 1 \\
\text { family protein }\end{array}$ & PGK1 & $\mathrm{Chl}$ & XP_002315066 & 351 & 7 & \\
\hline 3491 & $\begin{array}{l}\text { Phosphoglycerate kinase } 1 \\
\text { family protein }\end{array}$ & PGK1 & $\mathrm{Chl}$ & XP_002315066 & 351 & 7 & \\
\hline
\end{tabular}


Table 1. Cont

\begin{tabular}{|c|c|c|c|c|c|c|c|}
\hline $\begin{array}{l}\text { Spot } \\
\text { No. }{ }^{(a)}\end{array}$ & Protein Name ${ }^{(b)}$ & Abbreviation & $\begin{array}{l}\text { Subcellular } \\
\text { Location }^{(c)}\end{array}$ & $\begin{array}{l}\text { Accession } \\
\text { No. }{ }^{(d)}\end{array}$ & Sco ${ }^{(e)}$ & $\mathbf{Q M}^{(f)}$ & $\begin{array}{l}\mathrm{V} \% \pm \mathrm{SD}^{(g)} \\
0122436\end{array}$ \\
\hline 3687 & $\begin{array}{l}\text { Glyceraldehyde-3-phosphate } \\
\text { dehydrogenase A, chloroplastic* }\end{array}$ & GAPDH-A & Chl & ABK94956 & 484 & 6 & \\
\hline 3671 & $\begin{array}{l}\text { Glyceraldehyde-3-phosphate } \\
\text { dehydrogenase A, chloroplastic* }\end{array}$ & GAPDH-A & Chl & OIW03351 & 166 & 2 & \\
\hline 3670 & $\begin{array}{l}\text { Glyceraldehyde-3-phosphate } \\
\text { dehydrogenase A, chloroplastic* }\end{array}$ & GAPDH-A & Chl & OIW03351 & 113 & 2 & \\
\hline 3817 & $\begin{array}{l}\text { Fructose-bisphosphate aldolase 1, } \\
\text { chloroplastic* }^{*}\end{array}$ & FBA1 & Chl & ABK95613 & 164 & 3 & \\
\hline 3813 & Fructose-bisphosphate aldolase 3 & FBA3 & Chl & AGB05600 & 185 & 3 & \\
\hline 3816 & Fructose-bisphosphate aldolase 3 & FBA3 & Chl & AGB05600 & 196 & 3 & \\
\hline 3809 & Fructose-bisphosphate aldolase 3 & FBA3 & Chl & AGB05600 & 124 & 2 & \\
\hline 3802 & Fructose-bisphosphate aldolase 3 & FBA3 & Chl & AGB05600 & 133 & 2 & \\
\hline 3082 & Transketolase, chloroplastic & TK & $\mathrm{Chl}$ & KHG01555 & 99 & 2 & \\
\hline 3114 & Transketolase, chloroplastic & TK & Chl & EMT02862 & 120 & 2 & \\
\hline 4084 & Transketolase, chloroplastic & TK & Chl & Q43848 & 92 & 2 & \\
\hline 3639 & $\begin{array}{l}\text { Sedoheptulose-1,7-bisphosphatase, } \\
\text { chloroplastic* }\end{array}$ & SBPase & Chl & XP_002316235 & 57 & 2 & \\
\hline 3580 & $\begin{array}{l}\text { Sedoheptulose-1,7-bisphosphatase, } \\
\text { chloroplastic* }^{*}\end{array}$ & SBPase & Chl & OAY38482 & 101 & 3 & \\
\hline 3696 & Phosphoribulokinase, chloroplastic* & PRK & $\mathrm{Chl}$ & AOL56425 & 92 & 2 & d \\
\hline \multicolumn{8}{|c|}{ Carbohydrate and energy metabolism (12) } \\
\hline 3208 & Phosphoglucomutase, cytoplasmic & PGM & Cyt & Q9ZSQ4 & 115 & 3 & \\
\hline 3725 & $\begin{array}{l}\text { Glyceraldehyde-3-phosphate } \\
\text { dehydrogenase 2, cytosolic }\end{array}$ & GAPDH2 & Cyt & XP_002318114 & 374 & 4 & \\
\hline 3256 & Enolase & - & Cyt & Q42971 & 86 & 2 & \\
\hline 3506 & Alcohol dehydrogenase* & $\mathrm{ADH}$ & Cyt & XP_002302195 & 133 & 5 & \\
\hline 3500 & Alcohol dehydrogenase* & $\mathrm{ADH}$ & Cyt & XP_002302195 & 171 & 3 & \\
\hline 3701 & $\begin{array}{c}\text { NAD-dependent malate } \\
\text { dehydrogenase }\end{array}$ & NAD-MDH & Cyt & AAL11502 & 161 & 2 & \\
\hline 3702 & $\begin{array}{l}\text { NAD-dependent malate } \\
\text { dehydrogenase }\end{array}$ & NAD-MDH & Cyt & AAL11502 & 104 & 2 & \\
\hline 3710 & $\begin{array}{l}\text { NAD-dependent malate } \\
\text { dehydrogenase }\end{array}$ & NAD-MDH & Cyt & AAL11502 & 223 & 3 & \\
\hline 4448 & $\begin{array}{l}\text { Pyruvate dehydrogenase E1 } \\
\text { component subunit beta, } \\
\text { mitochondrial* }\end{array}$ & PDH E1- $\beta$ & Mit & GAU16570 & 249 & 3 & \\
\hline 3409 & $\begin{array}{l}\text { Pyruvate dehydrogenase E1 } \\
\text { component subunit beta, } \\
\text { mitochondrial* }\end{array}$ & PDH E1- $\beta$ & Mit & GAU16570 & 221 & 3 & \\
\hline
\end{tabular}


Table 1. Cont

\begin{tabular}{|c|c|c|c|c|c|c|c|}
\hline $\begin{array}{l}\text { Spot } \\
\text { No. }{ }^{(a)}\end{array}$ & Protein Name ${ }^{(b)}$ & Abbreviation & $\begin{array}{l}\text { Subcellular } \\
\text { Location }^{(c)}\end{array}$ & $\begin{array}{l}\text { Accession } \\
\text { No. }{ }^{(d)}\end{array}$ & Sco ${ }^{(e)}$ & $\mathbf{Q M}^{(f)}$ & $\begin{array}{l}\mathrm{V} \% \pm \mathrm{SD}^{(g)} \\
0122436\end{array}$ \\
\hline 4202 & $\begin{array}{l}\text { ATP synthase subunit } \mathrm{d} \\
\text { mitochondrial }{ }^{*}\end{array}$ & $\begin{array}{c}\text { mATP synthase } \\
\mathrm{d}\end{array}$ & Mit & CВI31501 & 89 & 2 & \\
\hline 4417 & $\begin{array}{l}\text { ATP synthase subunit beta, } \\
\text { mitochondrial * }\end{array}$ & $\underset{\beta}{\operatorname{mATP} \text { synthase }}$ & Mit & CDP00716 & 66 & 2 & \\
\hline \multicolumn{8}{|c|}{ Other metabolism (10) } \\
\hline 3611 & Glutamine synthetase & GS & Cyt & AGG19203 & 179 & 3 & \\
\hline 3604 & Glutamine synthetase & GS & Cyt & ABF06665 & 150 & 3 & \\
\hline 3841 & $\begin{array}{l}\text { O-acetylserine (thiol) lyase } \\
\text { family protein }\end{array}$ & OAS-TL & Uncertain & XP_006389317 & 70 & 2 & \\
\hline 3747 & $\begin{array}{l}\text { 3-isopropyl malate dehydrogenase, } \\
\text { chloroplastic }\end{array}$ & IPMDH & Chl & P29696 & 117 & 2 & \\
\hline 3402 & $\begin{array}{l}\text { Alanine aminotransferase } \\
\text { family protein }\end{array}$ & ALT & Uncertain & ALT55639 & 239 & 6 & \\
\hline 3515 & $\begin{array}{l}\text { Aldolase superfamily protein } \\
\text { isoform } 1 \text {, delta-aminolevulinic acid } \\
\text { dehydratase } 1 \text {, chloroplastic* }\end{array}$ & ALAD1 & Chl & EOY16322 & 92 & 3 & \\
\hline 3587 & Uroporphyrinogen decarboxylase & UROD & Chl & XP_011012304 & 272 & 4 & \\
\hline 3478 & $\begin{array}{c}\text { Anthocyanidin } \\
\text { 3-O-glucosyltransferase 2* }\end{array}$ & A3GT 2 & Uncertain & ABK96136 & 212 & 3 & \\
\hline 3798 & Isoflavone reductase family protein* & IFR & Cyt & ABK95019 & 133 & 3 & \\
\hline 3791 & 2-methylene-furan-3-one reductase* & MFOR & Chl & ABK96279 & 238 & 3 & \\
\hline \multicolumn{8}{|c|}{ Protein synthesis (1) } \\
\hline 3071 & Elongation factor G-2, chloroplastic* & EF-G2 & Chl & XP_002304430 & 108 & 4 & \\
\hline \multicolumn{8}{|c|}{ Protein folding and unfolding (8) } \\
\hline 3245 & $\begin{array}{l}\text { RuBisCO large subunit-binding } \\
\text { protein subunit } \alpha\end{array}$ & $\mathrm{RBP}-\alpha$ & Chl & XP_011000529 & 99 & 3 & \\
\hline 3133 & $\begin{array}{l}\text { Stromal } 70 \mathrm{kDa} \text { heat shock-related } \\
\text { family protein }\end{array}$ & cpHSP70 & $\mathrm{Chl}$ & XP_006389517 & 606 & 7 & \\
\hline 3102 & Chaperone DnaK & DnaK & $\mathrm{Chl}$ & KVI03056 & 445 & 7 & \\
\hline 3106 & Chaperone DnaK & DnaK & $\mathrm{Chl}$ & KVI03056 & 275 & 4 & \\
\hline 4395 & Heat shock cognate protein 80 & HSC 80 & Cyt & P36181 & 87 & 2 & \\
\hline 4397 & Heat shock protein 90 & HSP90 & Cyt & KVI10442 & 74 & 2 & \\
\hline 4398 & Heat shock protein 90 & HSP90 & Cyt & KVI10442 & 71 & 2 & \\
\hline 3814 & $\begin{array}{l}\text { Peptidyl-prolyl cis-trans isomerase } \\
\text { CYP26-2, chloroplastic* }\end{array}$ & CYP26-2 & $\mathrm{Chl}$ & XP_002318560 & 281 & 4 & \\
\hline \multicolumn{8}{|c|}{ Redox homeostasis and stress defense (4) } \\
\hline 4086 & Glutathione S-transferase U30 & GST-U30 & Cyt & ANO39995 & 74 & 2 & \\
\hline 4073 & Glutathione S-transferase F1 & GST-F1 & Cyt & ANO39924 & 164 & 2 & \\
\hline
\end{tabular}


Table 1. Cont.

\begin{tabular}{|c|c|c|c|c|c|c|c|}
\hline $\begin{array}{l}\text { Spot } \\
\text { No. }(a)\end{array}$ & Protein Name $^{(b)}$ & Abbreviation & $\begin{array}{l}\text { Subcellular } \\
\text { Location }^{(c)}\end{array}$ & $\begin{array}{l}\text { Accession } \\
\text { No. }{ }^{(d)}\end{array}$ & Sco $^{(e)}$ & $\mathbf{Q M}^{(f)}$ & $\begin{array}{c}\mathrm{V} \% \pm \mathrm{SD}^{(g)} \\
0122436\end{array}$ \\
\hline 3748 & Glyoxalase I homolog family protein & GlyI & Cyt & XP_002305564 & 88 & 2 & \\
\hline 3636 & Aldo/keto reductase family protein & AKR & Chl & XP_002302125 & 296 & 4 & \\
\hline \multicolumn{8}{|c|}{ Signaling (2) } \\
\hline 4249 & Nucleoside diphosphate kinase $1^{*}$ & NDPK1 & Cyt & ABK95604 & 139 & $25 \%$ & \\
\hline 3985 & 14-3-3-like protein $B^{*}$ & 14-3-3 B & Cyt & XP_002306545 & 119 & $12 \%$ & \\
\hline \multicolumn{8}{|c|}{ Cell structure (2) } \\
\hline 3419 & Tubulin $\alpha$ chain & Tubulin- $\alpha$ & Cyt & Q9FT36 & 101 & $12 \%$ & \\
\hline 4001 & $\begin{array}{l}\text { Plastid-lipid-associated protein } 6, \\
\text { chloroplastic* }\end{array}$ & PAP6 & Chl & AAR26489 & 154 & $18 \%$ & \\
\hline \multicolumn{8}{|c|}{ Miscellaneous or function unknown (5) } \\
\hline 3898 & $\begin{array}{l}\text { Haloacid dehalogenase-like } \\
\text { hydrolase family protein* }\end{array}$ & HAD & Chl & ABK96272 & 114 & $7 \%$ & \\
\hline 4457 & Pop3 peptide family protein* & Pop3 & Uncertain & 1SI9_A & 207 & $51 \%$ & \\
\hline 3662 & $\begin{array}{l}\text { Soybean genes regulated by cold } \\
\text { 2-like domain* }\end{array}$ & SRC2 & Uncertain & XP_011030162 & 136 & $10 \%$ & \\
\hline 4278 & $\begin{array}{l}\text { Stress responsive A/B barrel } \\
\text { domain* }\end{array}$ & SRB & Chl & CAA39082 & 132 & $24 \%$ & \\
\hline 3615 & Unknown protein & - & Secreted & ABK94923 & 93 & $7 \%$ & \\
\hline \multicolumn{8}{|c|}{$\begin{array}{l}{ }^{a} \text { Assigned spot number as indicated in Figure } 5 .{ }^{b} \text { The name of the proteins identified by MALDI TOF/TOF MS. } \\
\text { Protein names marked with an asterisk }\left({ }^{*}\right) \text { have been edited based on BLAST against NCBI non-redundant protein } \\
\text { database. The detailed information of the NCBI BLAST can be found in Table S2. }{ }^{c} \text { Protein subcellular localization } \\
\text { predicted by software YLoc, LocTree3, Plant-mPLoc, ngLOC, and TargetP. Chl, chloroplast; Cyt, cytoplasm; Mit, } \\
\text { mitochondrion. }{ }^{d} \text { Database accession numbers from NCBInr. }{ }^{e} \text { The Mascot score obtained after searching against } \\
\text { the NCBInr database. }{ }^{f} \text { The number of unique peptides identified for each protein. }{ }^{g} \text { The mean values of protein } \\
\text { spot volumes relative to total volume of all the spots. The different small letters on the columns indicate significant } \\
\text { differences }(p<0.05) \text { among the four samples as determined by one-way ANOVA. Error bars indicate } \pm \text { SD. }\end{array}$} \\
\hline
\end{tabular}

\subsection{Annotation and Functional Categorization of the $\mathrm{H}_{2} \mathrm{O}_{2}$-Responsive Proteins}

Among the $81 \mathrm{H}_{2} \mathrm{O}_{2}$-responsive proteins, 34 proteins were originally annotated as unknown, hypothetical proteins, or without annotation. They were all re-annotated according to the Basic Local Alignment Search Tool (BLAST) analysis (Table 1 and Table S3). Based on BLAST alignments, Gene Ontology, subcellular localization prediction, and information from literature, the 81 proteins were classified into ten functional categories including photosynthetic electron transfer chain, Calvin cycle, carbohydrate and energy metabolism, other metabolism, protein synthesis, protein folding and unfolding, redox homeostasis and stress defense, signaling, cell structure, and miscellaneous or function unknown (Table 1 and Figure 6A). Interestingly, proteins involved in photosynthetic electron transfer and Calvin cycle accounted for the largest group ( $46 \%$ of $\mathrm{H}_{2} \mathrm{O}_{2}$-responsive proteins). Besides, carbohydrate and energy metabolism $(15 \%)$, other metabolism $(12 \%)$, as well as protein folding and unfolding $(10 \%)$ were also over-represented. 

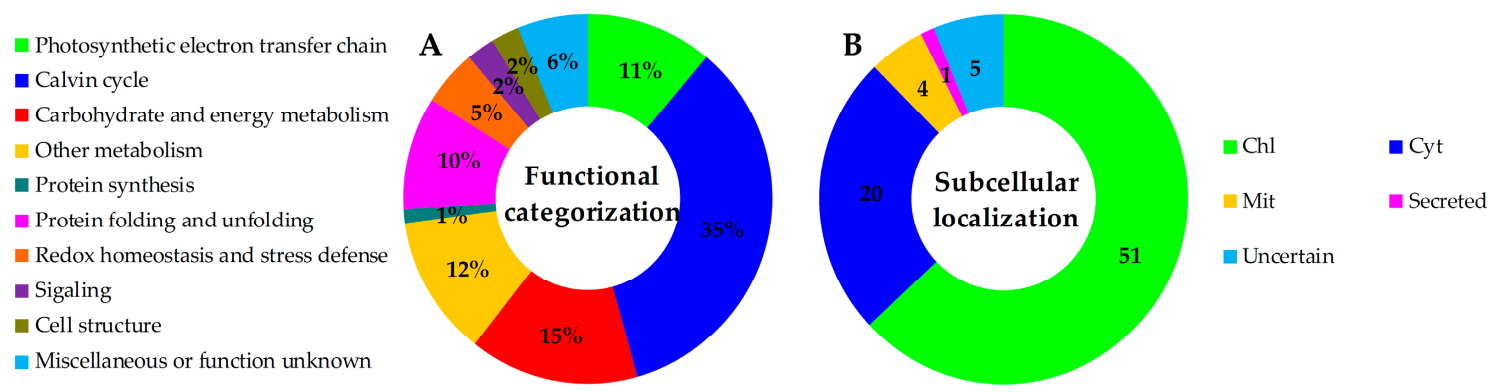

Figure 6. Functional categorization and subcellular localization of the identified $81 \mathrm{H}_{2} \mathrm{O}_{2}$-responsive proteins from leaves of Populus simonii $\times$ Populus nigra. (A) The functional categories: The percentage of proteins in different functional categories is shown in the pie; (B) Subcellular localization groups of the identified proteins: The numbers of proteins with different locations are shown. Chl, chloroplast; Cyt, cytoplasm; Mit, mitochondrion.

\subsection{Subcellular Localization and Hierarchical Clustering of $\mathrm{H}_{2} \mathrm{O}_{2}$-Responsive Proteins}

The subcellular localization of the 81 proteins was predicted using five different tools (i.e., YLoc, LocTree3, Plant-mPLoc, ngLOC, and TargetP) (Figure 6B, Table 1 and Table S4). In total, 51 proteins $(63 \%)$ were predicted to be localized in chloroplasts, 20 in cytoplasm, four in mitochondria, one secreted, and five uncertain. This implied that most chloroplast proteins were obviously affected by $\mathrm{H}_{2} \mathrm{O}_{2}$.

\subsection{Hierarchical Clustering and Analysis of $\mathrm{H}_{2} \mathrm{O}_{2}$-Responsive Proteins}

To better understand the abundance patterns of the coordinately regulated proteins, hierarchical clustering analysis of the $81 \mathrm{H}_{2} \mathrm{O}_{2}$-responsive proteins were performed, which revealed four main clusters (Figure 7). Cluster I included a total of 42 proteins, as the most group cluster, which included the significantly decreased proteins under $\mathrm{H}_{2} \mathrm{O}_{2}$ treatment. Cluster II included the proteins decreased under $12 \mathrm{mM}$, but increased under 24 or $36 \mathrm{mM} \mathrm{H}_{2} \mathrm{O}_{2}$ treatment. Cluster III contained the proteins unchanged or increased under relative lower concentration of $\mathrm{H}_{2} \mathrm{O}_{2}$ stress, but decreased under relative higher concentration, especially $36 \mathrm{mM} \mathrm{H}_{2} \mathrm{O}_{2}$ treatment. Several proteins involved in carbohydrate and energy metabolism were grouped into this subcluster. Cluster IV contained six proteins whose abundances were increased under $\mathrm{H}_{2} \mathrm{O}_{2}$ treatment. Notably, several heat shock proteins (HSPs) were categorized into Cluster IV.

\subsection{Protein-Protein Interaction (PPI) among $\mathrm{H}_{2} \mathrm{O}_{2}$-Responsive Proteins}

To discover the relationship of the $81 \mathrm{H}_{2} \mathrm{O}_{2}$-responsive proteins, the PPI networks were generated using the web-tool STRING 10 [30]. Among the $81 \mathrm{H}_{2} \mathrm{O}_{2}$-responsive proteins, 59 unique homologous proteins were found in Arabidopsis (Table S5) [31]. Out of the 59 proteins, 40 proteins were depicted in the STRING database (Figure 8). Six modules forming tightly connected clusters were illuminated, and stronger associations were represented by thicker lines in the networks (Figure 8). Twelve and nine proteins were connected in Module 1 and Module 2, respectively. Most of them were involved in photosynthesis or carbohydrate metabolism. Module 3 contained five proteins mainly involved in energy metabolism, and Module 4 contained six proteins mainly involved in protein folding. Three proteins involved in amino acid metabolism were assigned in Module 5. 

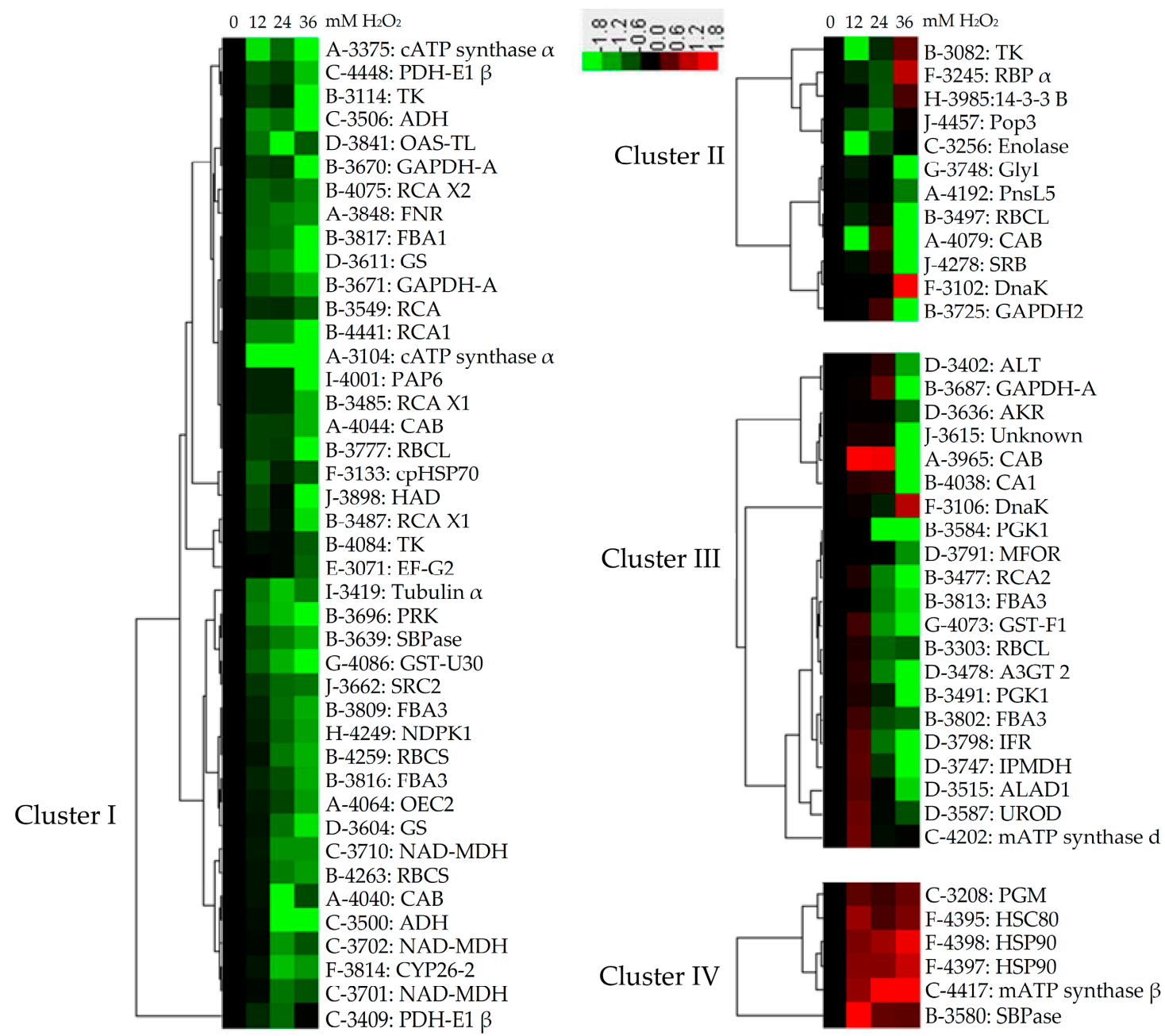

Figure 7. Hierarchical clustering analysis of $81 \mathrm{H}_{2} \mathrm{O}_{2}$-responsive proteins in leaves of Populus simonii $\times$ Populus nigra. The four columns represent different treatments, including 0, 12, 24 and $36 \mathrm{mM} \mathrm{H}_{2} \mathrm{O}_{2}$. The rows represent individual proteins. The increased or decreased proteins are indicated in red or green, respectively. The color intensity increases with increasing abundant differences, as shown in the scale bar. The scale bar indicates log (base2) transformed protein abundance ratios ranging from -1.8 to 1.8. Functional categories indicated by capital letters, spot numbers, and protein names are listed on the right side. A, photosynthetic electron transfer chain; B, Calvin cycle; C, carbohydrate and energy metabolism; D, other metabolisms; E, protein synthesis; F, protein folding and unfolding; $\mathrm{G}$, redox homeostasis and stress defense; $\mathrm{H}$, signaling; I, cell structure; J, miscellaneous or function unknown. The abbreviations refer to Table 1. 


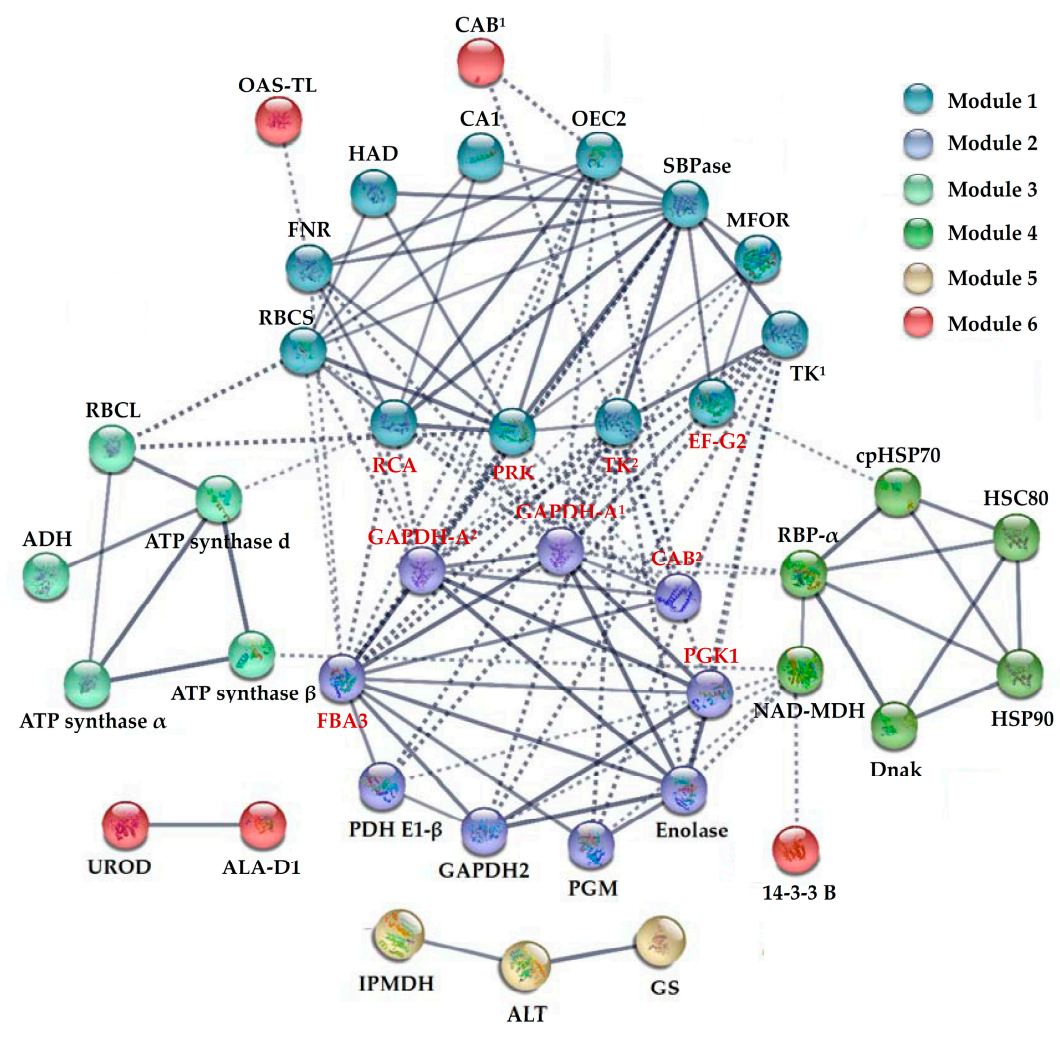

Figure 8. The protein-protein interaction (PPI) network in Populus simonii $\times$ Populus nigra leaves revealed by STRING analysis. A total of $81 \mathrm{H}_{2} \mathrm{O}_{2}$-responsive proteins represented by 59 unique homologous proteins from Arabidopsis are shown in PPI network. Six main groups are indicated in different colors. The PPI network is shown in the confidence view generated by STRING database. Stronger associations are represented by thicker lines. The abbreviations refer to Table 1.

\section{Discussion}

\section{1. $\mathrm{H}_{2} \mathrm{O}_{2}$-Responsive Signal Transduction and Cellular Structure Modulation in Poplar}

$\mathrm{H}_{2} \mathrm{O}_{2}$ is generally regarded as a signal molecule in various abiotic/biotic stress-responsive pathways [6-12]. In this study, two signaling transduction-related proteins, 14-3-3 like protein $\mathrm{B}$ and nucleoside diphosphate kinase 1 (NDPK1), were altered in the $\mathrm{H}_{2} \mathrm{O}_{2}$-treated leaves of P. simonii $\times$ P. nigra. 14-3-3 like protein $\mathrm{B}$ was increased remarkably under $36 \mathrm{mM} \mathrm{H}_{2} \mathrm{O}_{2}$ (Table 1 and Figure 9A). Similarly, 14-3-3 like protein GF14-D was accumulated in B. distachyon leaves under $20 \mathrm{mM} \mathrm{H}_{2} \mathrm{O}_{2}$ for $4 \mathrm{~h}$ [19]. Plant 14-3-3 family proteins mediate the regulation of distinct biological processes by binding to phosphorylated client proteins. Recent proteome-wide in vivo approaches indicated that 14-3-3 proteins might interact with more than 100 target proteins in Arabidopsis [32]. Especially, plant 14-3-3 family was confirmed to be responsive to various environmental stresses [33]. In addition, NDPKs are multifunctional proteins that regulate a variety of eukaryotic cellular activities [34]. We found that NDPK1 was reduced in poplar leaves under $\mathrm{H}_{2} \mathrm{O}_{2}$ stress (Table 1 and Figure 9A), which was also reduced in Arabidopsis leaves in response to $3 \mathrm{mM} \mathrm{H}_{2} \mathrm{O}_{2}$ for five days [20]. However, $\mathrm{H}_{2} \mathrm{O}_{2}$ stress strongly induced the expression of AtNDPK2 gene in Arabidopsis, which was associated with $\mathrm{H}_{2} \mathrm{O}_{2}$-mediated mitogen-activated protein kinase signaling in plants [34]. The different $\mathrm{H}_{2} \mathrm{O}_{2}$-responsive patterns between NDPK1 and NDPK2 may be attributed to the different functions of various plant NDPK types [35]. For instance, cytoplasm-localized Type I NDPKs are involved in growth, metabolism and stress responses, whereas chloroplast-localized Type II NDPKs are involved in photosynthetic development and oxidative stress management [35]. The specific functions of the NDPK family members need to be investigated in polar in response to $\mathrm{H}_{2} \mathrm{O}_{2}$. 


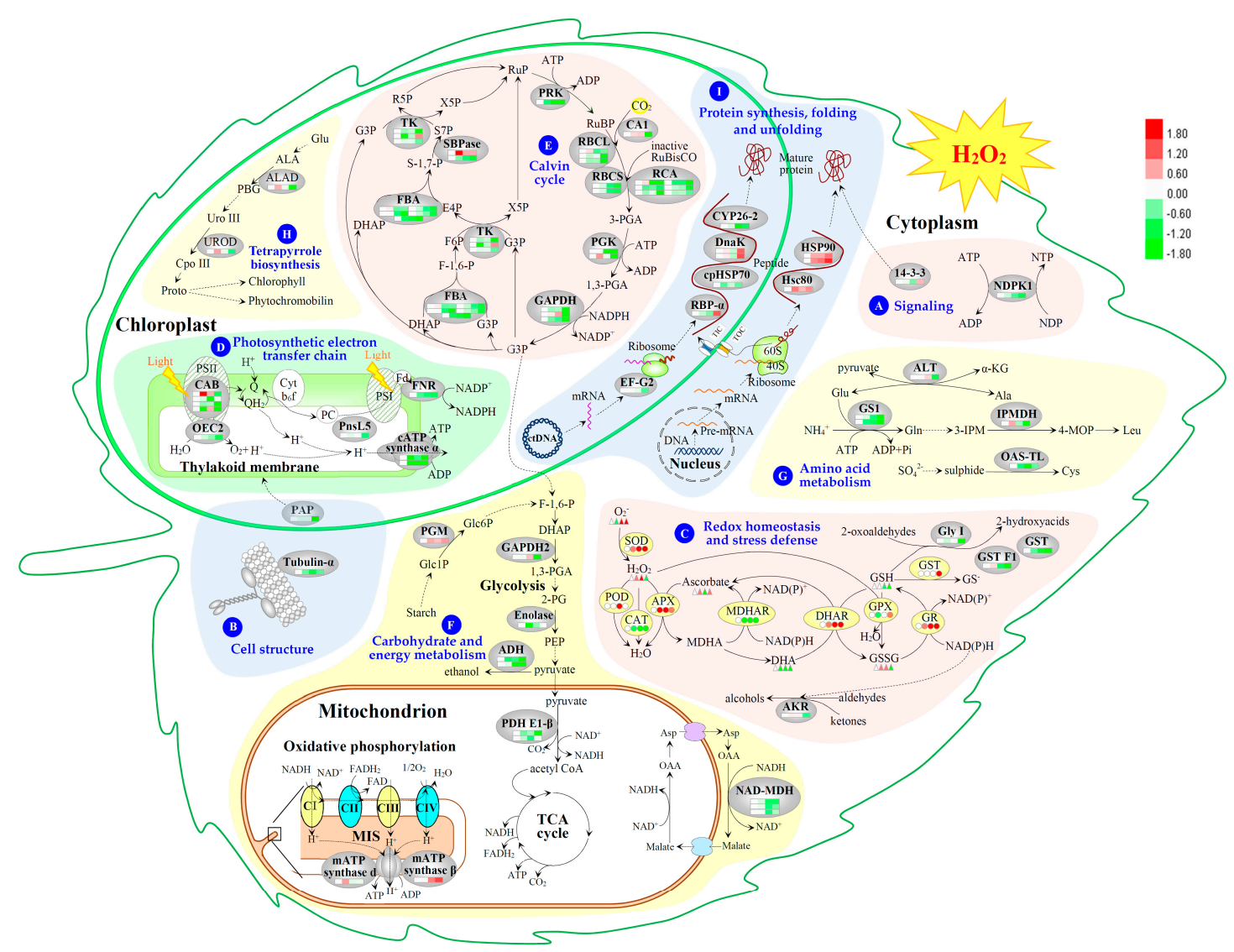

Figure 9. Schematic presentation of $\mathrm{H}_{2} \mathrm{O}_{2}$-responsive mechanism in leaves of Populus simonii $\times$ Populus nigra. The identified proteins were integrated into subcellular pathways: (A) signaling; (B) cell structure; (C), redox homeostasis and stress defense; (D) photosynthetic electron transfer chain; (E) calvin cycle; (F) carbohydrate and energy metabolism; (G) amino acid metabolism; (H) tetrapyrrole biosynthesis; and (I) protein synthesis, folding and unfolding. The abundances of identified proteins (shaded in gray ovals), enzyme activities (shaded in yellow ovals), and substrate contents are marked with squares, circles and triangles in different colors, respectively. The increased and decreased proteins, enzyme activities, and substrate contents are represented in red and green, respectively. The color intensity increases with increasing differences. The solid line indicates single-step reaction, the dashed line indicates multistep reaction, and the dotted line indicates the movement of proteins or substances. The abbreviations of identified proteins refer to Table 1. The abbreviations of metabolites: 1,3-PGA, 1,3-bisphosphoglycerate; 2-PG, 2-phosphoglycerate; 3-IPM, 3-isopropylmalate; 3-PGA, 3-phosphoglycerate; 4-MOP, 4-methyl-2-oxopentanoate; ADP, adenosine diphosphate; ALA, 5-aminolevulinicacid; Ala, alanine; Asp, aspartate; ATP, adenosine-triphosphate; CpoIII, coproporphyrinogen III; ctDNA, chloroplast DNA; Cys, cysteine; DHA, dehydroascrobate; DHAP, dihydroxyacetone phosphate; E4P, erythrose-4-phosphate; F-1,6-P, fructose-1,6-bisphosphate; F6P, fructose-6-phosphate; $\mathrm{FADH}_{2}$, reduced flavin adenine dinucleotide; Fd, ferredoxin; G3P, glyceraldehyde-3-phosphate; Glc1P, glucose-1-phosphate; Glc6P, glucose-6-phosphate; Gln, glutamine; Glu, glutamate; GSH, reduced glutathione; GSSG, oxidized glutathione; Leu, leucine; MDHA, monodehydroascrobate; MIS, mitochondrial intermembrane space; $\mathrm{NAD}^{+} / \mathrm{NADH}$, nicotinamide adenine dinucleotide; $\mathrm{NADP}^{+} / \mathrm{NADPH}$, nicotinamide adenine dinucleotide phosphate; NDP, nucleoside diphosphate; NTP, nucleoside triphosphate; OAA, oxaloacetic acid; PBG, porphobilinogen; PC, plastocyanin; PEP, phosphoenolpyruvate; pre-mRNA, precursor mRNA; Proto, protoporphyrin IX; PSI, photosystem I; PSII, photosystem II; Q, quinone; R5P, ribulose-5-phosphate; RuBP, ribulose-1,5-bisphosphate; RuP, ribulose-5-phosphate; S-1,7-P, sedoheptulose-1,7-bisphosphate; $\mathrm{S7P}$, sedoheptulose-7-phosphate; TIC, translocon at the inner envelope membrane of chloroplasts; TOC, translocon at the outer envelope membrane of chloroplasts; UroIII, uroporphyrinogen III; X5P, xylulose-5-phosphate; $\alpha$-KG, $\alpha$-ketoglutarate. 
Excessive $\mathrm{H}_{2} \mathrm{O}_{2}$ can damage protein and lipid structure, leading to the destruction of cell membrane stability. In this study, the increases of MDA content and REL implied that $\mathrm{H}_{2} \mathrm{O}_{2}$ induced plasma membrane lipid peroxidation and plasma membrane permeability in leaves of poplar (Figure 3A,B). Importantly, our proteomics results indicated that plastid lipid associated proteins (PAPs) and tubulin were $36 \mathrm{mM} \mathrm{H}_{2} \mathrm{O}_{2}$-reduced in leaves (Figure 9B). PAPs, also termed as fibrillin/CDSP34 proteins, are involved in the structural stabilization of thylakoid membrane upon environmental constraints. The gene expression and protein accumulation of PAPs were induced in tomato (Lycopersicon esculentum) and potato (Solanum tuberosum) under osmotic and oxidative stresses [36,37]. Besides, the expression of PAPs in Brassica napus and Arabidopsis were differentially regulated by various abiotic stresses, such as drought, ozone, cold, $\mathrm{NaCl}$, light, and mechanical wounding $[38,39]$. The $\alpha / \beta$-tubulin heterodimer is the building block of microtubules, which regulates cell division and expansion, as well as organelle movement. Microtubule organization and dynamics quickly responds to various external stress signals, such as low temperature [40], cold acclimation [41], as well as osmotic and salt stresses [42,43]. All these imply that cell structure modulation is critical for the tolerance of various exogenous stresses-induced intracellular oxidative stress in poplar.

\section{2. $\mathrm{H}_{2} \mathrm{O}_{2}$-Induced Alteration of ROS Scavenging Pathways in Poplar}

Generally, when leaves are exposed to $\mathrm{H}_{2} \mathrm{O}_{2}$ treatment, exogenous $\mathrm{H}_{2} \mathrm{O}_{2}$ can permeate through cell membrane into cells, leading to the increase of intracellular $\mathrm{H}_{2} \mathrm{O}_{2}$ level [17]. In this study, the $\mathrm{H}_{2} \mathrm{O}_{2}$ concentrations in leaves were increased under 12 and $24 \mathrm{mM} \mathrm{H}_{2} \mathrm{O}_{2}$ (Figure 4A). Interesting, the intracellular $\mathrm{H}_{2} \mathrm{O}_{2}$ levels were increased in leaves of grass pea (Lathyrus sativu L.) under 5 and $10 \mathrm{mM} \mathrm{H}_{2} \mathrm{O}_{2}$ for $24 \mathrm{~h}$, but returned to the normal level under $20 \mathrm{mM} \mathrm{H}_{2} \mathrm{O}_{2}$, which were revealed from $\mathrm{H}_{2} \mathrm{O}_{2}$ content detection and the histochemical localization using DAB staining [44]. These implied that special pathways were employed for intracellular $\mathrm{H}_{2} \mathrm{O}_{2}$ scavenging when plants were exposed to relatively higher concentration of $\mathrm{H}_{2} \mathrm{O}_{2}$.

In poplar leaves, we found diverse antioxidative enzymes and antioxidants were involved in intracellular $\mathrm{H}_{2} \mathrm{O}_{2}$ scavenging to cope with exogenous $\mathrm{H}_{2} \mathrm{O}_{2}$ stress (Figure 9C). The increase of SOD activity would contribute to dismutase intracellular $\mathrm{O}_{2}{ }^{\bullet-}$ to $\mathrm{H}_{2} \mathrm{O}_{2}$ in leaves under 24 and $36 \mathrm{mM} \mathrm{H}_{2} \mathrm{O}_{2}$ stress (Figure $4 \mathrm{~B}$ ). Interestingly, other primary antioxidative enzymes showed distinct activity patterns in response to various $\mathrm{H}_{2} \mathrm{O}_{2}$ concentrations. The activities of APX, POD, and GPX were induced under 12,24 and $36 \mathrm{mM} \mathrm{H}_{2} \mathrm{O}_{2}$, respectively, indicating that different antioxidative pathways were employed under certain $\mathrm{H}_{2} \mathrm{O}_{2}$ level (Figure $4 \mathrm{C}$,D). Similar results were also obtained in $\mathrm{H}_{2} \mathrm{O}_{2}$-stressed grass pea (Lathyrus sativus L.). The activities of APX and POD were increased under 5 and $10 \mathrm{mM} \mathrm{H}_{2} \mathrm{O}_{2}$, but returned to the normal level under $20 \mathrm{mM} \mathrm{H}_{2} \mathrm{O}_{2}$ [44]. Importantly, in this study, the induced GPX activity would especially facilitate to reduce relative higher intracellular $\mathrm{H}_{2} \mathrm{O}_{2}$ levels (Figure 4D), and enhance the reduction of lipid peroxide for defensing against oxidative membrane damage in poplar leaves under $36 \mathrm{mM} \mathrm{H}_{2} \mathrm{O}_{2}$ stress [45]. Unexpectedly, the $\mathrm{H}_{2} \mathrm{O}_{2}$-reduced CAT activity implied that the intracellular $\mathrm{H}_{2} \mathrm{O}_{2}$ would not be mainly scavenged in peroxisome when poplar leaves expose to extracellular $\mathrm{H}_{2} \mathrm{O}_{2}$ stress (Figure 4B) [1].

The activities of several antioxidative enzymes (e.g., MDHAR, DHAR, and GR) were $\mathrm{H}_{2} \mathrm{O}_{2}$-modulated for regeneration of reduced AsA and GSH, such as reduced MDHAR activity, and increased activities of DHAR and GR in poplar (Figure 4E,F). MDHAR and DHAR catalyze the regeneration of AsA, using nicotinamide adenine dinucleotide phosphate (NADPH) and GSH as electron source/donor, respectively, while GR maintains the cellular reduced GSH pool through converting GSSG to GSH with NADPH. The stress-induced activities of DHAR and GR also have been reported in several plants (e.g., maize and pepper) in response to abiotic stresses, such as salinity, drought, low temperature, and heavy metal [46]. This suggests that the $\mathrm{H}_{2} \mathrm{O}_{2}$-induced activities of DHAR and GR would maintain the reduced AsA and GSH pools for antioxidative processes in leaves. In addition, the altered $\mathrm{H}_{2} \mathrm{O}_{2}$-reponsive contents of antioxidants AsA/DHA and GSH/GSSG indicated that they contributed to $\mathrm{H}_{2} \mathrm{O}_{2}$ scavenging, which would function as the substances of aforementioned 
antioxidative enzyme (i.e., APX, POD, GPX, and DHAR) systems, but also could directly reduce $\mathrm{H}_{2} \mathrm{O}_{2}$ as reductants in poplar leaves. Additionally, the exogenous $\mathrm{H}_{2} \mathrm{O}_{2}$-induced osmolytes (i.e., proline, soluble sugar, and glycine betaine) were suggested to protect cellular components from degeneration by scavenging ROS in poplar leaves (Figure 3C-E). Similarly, the accumulation of proline and soluble sugars was found in wheat leaves under $\mathrm{H}_{2} \mathrm{O}_{2}$ treatment [20].

\section{3. $\mathrm{H}_{2} \mathrm{O}_{2}$-Altered Redox Homeostasis in Poplar Leaves}

In addition to the ROS scavenging pathways, glutathione-S-transferase (GST), glyoxylase (Gly) and aldo/keto reductase (AKR) were altered in regulating secondary release of metabolite signals in poplar leaves to cope with $\mathrm{H}_{2} \mathrm{O}_{2}$ stress. GSTs are mostly known as detoxifiers of electrophilic compounds by covalently linking glutathione to hydrophobic substrates for sequestration or removal, which plays an important role in improving plant stress tolerance [47]. In this study, GST activity was increased significantly under $36 \mathrm{mM} \mathrm{H}_{2} \mathrm{O}_{2}$, but the abundances of GST U30 and GST F1 were decreased (Figures $4 \mathrm{~F}$ and $9 \mathrm{C}$, and Table 1 ). It can be explained that the enzyme activity is determined by not only protein abundance, but also its changes in conformation and post-translational modification (PTM). Moreover, plant GST group is a large protein family containing at least eight classes, and each family member has different role in response to various stress conditions. For example, the abundances of $B$. distachyon GST1-like [19] and citrus GST [18] were $\mathrm{H}_{2} \mathrm{O}_{2}$-decreased in leaves, but the abundances of wheat GST 19E50 [20] and rice GST F11 [17] were $\mathrm{H}_{2} \mathrm{O}_{2}$-increased in leaves. Therefore, in this study, the reduced abundances of two GST members would not account for the overall GST activity in polar leaves to cope with $\mathrm{H}_{2} \mathrm{O}_{2}$. The PTM mechanisms of GSTs are valuable to be further investigated.

Gly system comprising of Gly I and Gly II is the primary route for detoxification of methylglyoxal that is a toxic byproduct inhibiting cell proliferation, protein degradation, and antioxidant defense system [48]. Gly I was accumulated in rice leaves under 0.6 and $3 \mathrm{mM} \mathrm{H}_{2} \mathrm{O}_{2}$ stresses [17], but decreased in citrus leaves under $10 \mathrm{mM}$ for $8 \mathrm{~h}$ [18]. In addition, AKRs are involved in detoxifying lipid peroxidation derived reactive aldehydes, leading to enhance the tolerance against abiotic stress-induced oxidative stress [49]. In this study, all the abundances of Gly I and AKR maintained at normal levels under 12 and $24 \mathrm{mM} \mathrm{H}_{2} \mathrm{O}_{2}$, but decreased significantly under $36 \mathrm{mM} \mathrm{H}_{2} \mathrm{O}_{2}$ (Table 1 and Figure 9C). This implied that Gly and AKR systems were probably employed for detoxification under relative lower concentration of $\mathrm{H}_{2} \mathrm{O}_{2}$ stress.

\section{4. $\mathrm{H}_{2} \mathrm{O}_{2}$-Reduced Photosynthesis in Poplar}

Photosynthesis is sensitive to ROS accumulation resulted from diverse stresses, because most photosynthetic enzymes are the preferential targets for the oxidation. In this study, the $\mathrm{H}_{2} \mathrm{O}_{2}$ immersion resulted in the decreases of net photosynthesis and stomatal conductance of $P$. simonii $\times$ P. nigra seedlings (Figure 2A,B). Importantly, we found $37 \mathrm{H}_{2} \mathrm{O}_{2}$-responsive proteins were involved in photosynthesis, which accounted for $46 \%$ of all the $\mathrm{H}_{2} \mathrm{O}_{2}$-responsive proteins in poplar leaves (Table 1, and Figures 6A and 9D,E). This is similar to what happened in leaves from rice under 0.6 and $15 \mathrm{mM} \mathrm{H}_{2} \mathrm{O}_{2}$ for $6 \mathrm{~h}$ and citrus under $10 \mathrm{mM} \mathrm{H}_{2} \mathrm{O}_{2}$ for $8 \mathrm{~h}$, respectively [17,18]. In these two studies, $32 \%$ and $28 \% \mathrm{H}_{2} \mathrm{O}_{2}$-responsive proteins in rice and citrus were identified using 2DE-based proteomics approaches, respectively $[17,18]$. These proteins are involved in light harvest, oxygen evolving, electron transfer, ATP synthesis, and Calvin cycle. Most of them were decreased under certain $\mathrm{H}_{2} \mathrm{O}_{2}$ concentration, leading to photosynthesis decline in poplar (Figures 2A and 9D,E, and Table 1). Interestingly, most of these proteins, except for PnsL5, were changed in $\mathrm{H}_{2} \mathrm{O}_{2}$-treated leaves from other trees (e.g., citrus [18]) and gramineous plants (e.g., rice [17], wheat [20], and B. distachyon [19]).

In this study, our 2DE-based proteomics investigation revealed that ten of the $\mathrm{H}_{2} \mathrm{O}_{2}$-resposive photosynthetic proteins had multi-proteoforms in poplar leaves in response to $\mathrm{H}_{2} \mathrm{O}_{2}$ (Table 1 and Figure 9D,E). These proteoforms were mainly resulted from various $\mathrm{H}_{2} \mathrm{O}_{2}$-induced PTMs, including oxidative modification. All these proteins have been found to be oxidized in Arabidopsis in response to $\mathrm{H}_{2} \mathrm{O}_{2}$ treatments using redox proteomics approaches [50-53]. This is consistent with the findings 
from citrus and Arabidopsis that most photosynthesis-related proteins were easily carbonylated [18] and/or oxidized [51] under $\mathrm{H}_{2} \mathrm{O}_{2}$ exposure. Therefore, it is necessary to investigate the protein redox PTMs using redox proteomics technologies.

\section{5. $\mathrm{H}_{2} \mathrm{O}_{2}$-Responsive Carbohydrate and Other Metabolisms in Poplar}

Carbohydrate and energy supply are essential for plants in response to oxidative stress [20]. Our proteomics results revealed that phosphoglucomutase (PGM), cytosolic GAPDH, and enolase were altered in poplar leaves under $\mathrm{H}_{2} \mathrm{O}_{2}$ stress (Figure 9F). The increase of cytosolic PGM would enhance reversible interconversion of glucose-1-phosphate and glucose-6-phosphate, providing substrates for glycolysis and synthesis of a variety of cellular constituents. In roots of two black poplar (P. nigra) clones, the PGM gene and soluble sugar level were all induced under drought stress [54]. This implied that the mobilization of stored starch would be triggered in poplar when carbon assimilation was inhibited due to oxidization stress-reduced photosynthesis [54]. Besides, the $\mathrm{H}_{2} \mathrm{O}_{2}$-decreased abundances of cytosolic GAPDH and enolase implied that glycolysis was inhibited in poplar under $\mathrm{H}_{2} \mathrm{O}_{2}$ stress. In addition, the decreased abundances of alcohol dehydrogenase and cytosolic NAD-dependent malate dehydrogenase would reduce the regeneration of reducing power nicotinamide adenine dinucleotide (NADH) in $\mathrm{H}_{2} \mathrm{O}_{2}$-stressed poplar leaves [55,56], while the abundance-altered pyruvate dehydrogenase E1 and mitochondria ATP synthase would contribute for modulation of tricarboxylic acid cycle and energy supply in $\mathrm{H}_{2} \mathrm{O}_{2}$-stressed poplar leaves.

Glutamate and cysteine are central metabolites that serve as donors for the synthesis of other amino acids, vitamins, coenzymes, GSHs, and proteins, which play critical roles in plant stress responses. The syntheses of glutamine/glutamate and cysteine are depended on glutamine synthetase (GS)-involved pathway [57] and O-acetylserine (thiol) lyase (OAS-TL)-involved pathway [58], respectively. In this study, two proteoforms of cytosolic GS and OAS-TL were decreased in poplar leaves under $\mathrm{H}_{2} \mathrm{O}_{2}$ stress (Table 1, Figure 9G). The oxidative-decreased GS was also found in wheat leaves under $15 \mathrm{mM} \mathrm{H}_{2} \mathrm{O}_{2}$ for five days [20]. In addition, two other amino acid metabolism-related enzymes (i.e., 3-isopropyl malate dehydrogenase and alanine aminotransferase family protein) were decreased in poplar leaves under $36 \mathrm{mM} \mathrm{H}_{2} \mathrm{O}_{2}$ stress (Table 1 and Figure 9G). These proteomics results implied that amino acid metabolism was reduced in poplar leaves under $\mathrm{H}_{2} \mathrm{O}_{2}$ stress.

In addition, two enzymes in plant tetrapyrrole biosynthetic pathway, delta-aminolevulinic acid dehydratase 1 (ALAD1) and uroporphyrinogen decarboxylase (UROD), were all decreased under $36 \mathrm{mM} \mathrm{H}_{2} \mathrm{O}_{2}$ stress (Table 1, Figure 9H). ALAD catalyzes the asymmetric condensation of two molecules of $\delta$-aminolevulinic acid to porphobilinogen, and UROD catalyzes the formation of coproporphyrinogen from uroporphyrinogen. Altered ALAD activity concomitant with reduced chlorophyll content have been reported in many terrestrial plants exposed to various metal (e.g., aluminum, cadmium, and lead) stresses [59-61]. Interestingly, transgenic tobacco plants with reduced activity of UROD was characterized by the accumulation of photosensitizing tetrapyrrole intermediates, which would induce the enzymatic detoxifying defense system, and especially resemble the hypersensitive reaction observed after pathogen attack [62]. Thus, the reduction of ALAD1 and UROD might result in the accumulation of photosensitizing tetrapyrrole intermediates, which probably play roles in the response of $\mathrm{H}_{2} \mathrm{O}_{2}$.

\section{6. $\mathrm{H}_{2} \mathrm{O}_{2}$-Responsive Proteins Conformation in Poplar}

Maintaining proteins in their functional conformations and preventing the aggregation of non-native proteins are important for plant survival under oxidative conditions. HSPs and other chaperones are responsible for protein folding, assembly, translocation, and degradation in response to stress conditions [63]. In this study, a RuBisCO large subunit-binding protein $\alpha$ subunit (RBP- $\alpha$ ) and two proteoforms of chaperone DnaK (DnaK) were increased remarkably in poplar under $36 \mathrm{mM} \mathrm{H}_{2} \mathrm{O}_{2}$ stress (Table 1 and Figure 9I). RBP is considered as chloroplast chaperonin 60 (Cpn60), which is most likely involved in mature protein folding/assembly in plants, and facilitates the translocated protein to 
fold into native conformation. Previous studies showed that RBPs were induced in wheat leaves under drought [64] and salt stress [65], as well as in rice leaves by $\mathrm{H}_{2} \mathrm{O}_{2}$ stress [17]. Moreover, $\mathrm{Cpn} 60$ subunit $\beta$ can protect $\mathrm{RuBis} C \mathrm{O}$ activase from thermal denaturation and function in acclimating photosynthesis to heat stress [66]. In this study, the two proteoforms of DnaK in poplar have relatively high sequence similarity to chloroplast HSPs [67]. The chloroplast HSPs carry out pivotal function in processes related to growth and development and in response to diverse environmental stresses, such as heat, light, and pathological stress [67]. For example, the expression of the chloroplast-localized Hsp70B is induced in Chlamydomonas under heat shock, high light and oxidative stresses [68]. A wheat chloroplast TaHsp70 plays a critical role in defense response elicited by infection of stripe rust fungus [69]. Therefore, the increases of RBP- $\alpha$ and DnaKs in poplar under $36 \mathrm{mM} \mathrm{H}_{2} \mathrm{O}_{2}$ treatment suggest they play an important role in protection against the high dose oxidative stress.

In addition, heat shock cognate protein 80 (HSC80) and two proteoforms of heat shock protein 90 (HSP90) were increased in poplar under $\mathrm{H}_{2} \mathrm{O}_{2}$ stress (Table 1, Figure 9I). HSC80 was found to be increased 10-fold in tomato cell culture upon heat shock [70]. HSP90 is distinct from many other molecular chaperones in that most of its known substrates to date are signal transduction-related proteins such as steroid hormone receptors and signaling kinases [63]. Recent studies revealed that plant HSP90s were important in plant development, environmental stress response, as well as disease and pest resistance [71]. Therefore, the induced HSC 80 and HSP90s might prevent the aggregation of non-native proteins and reestablish normal protein conformation in $\mathrm{H}_{2} \mathrm{O}_{2}$-stressed poplar leaves.

\section{Methods}

\subsection{Plant Cultivation and Treatment}

The terminal buds or lateral buds excised from P. simonii $\times$ P. nigra plantlets were transferred to a culture flask containing $80 \mathrm{~mL} 1 / 2 \mathrm{MS}$ solid medium, containing $2 \%(w / v)$ sugar and $0.54 \%(w / v)$ agar. The explants were cultured in a phytotron at $26{ }^{\circ} \mathrm{C} / 22{ }^{\circ} \mathrm{C}$ (day/night), $16 \mathrm{~h}$ photoperiod and $200 \mu \mathrm{mol} \cdot \mathrm{m}^{-2} \cdot \mathrm{s}^{-1}$ light intensity for 50 days. The shoots of regenerated plantlets were immersed in $0,12,24$ and $36 \mathrm{mM} \mathrm{H}_{2} \mathrm{O}_{2}$ for $6 \mathrm{~h}$, respectively. After the treatments, leaves were harvested and blotted dry on filter paper immediately. For each treatment, at least three biological replicates were performed. For each replicate, more than three whole leaves with similar size from at least three separate poplar seedlings were collected and pooled. The fresh weight was $0.2 \mathrm{~g}$. The samples were either used fresh or stored at $-80^{\circ} \mathrm{C}$ for future analysis.

\subsection{Photosynthesis Measurement}

Pn, Gs, Ci, and Tr were measured in fully expanded leaves of each plant using a portable photosynthesis system LICOR 6400 XT (LI-COR Inc., Lincoln, NE, USA) [72]. The measurements were done at 10:00 a.m. At least nine leaves for each sample were measured.

\subsection{Determination of MDA Content, REL, Total Soluble Sugar, Proline, and Glycine Betaine Contents}

The MDA content and REL were determined using previous methods described by Wang et al. [73].

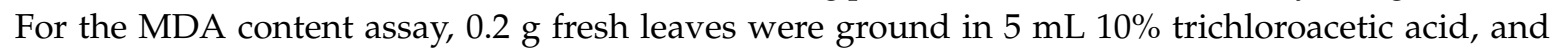
centrifuged at $10,000 \times g$ at $4{ }^{\circ} \mathrm{C}$ for $10 \mathrm{~min}$, then the supernatant was collected. Two milliliters of $0.6 \%$ $(w / v)$ thiobarbituric acid solution was added to $2 \mathrm{~mL}$ of the supernatant. The reaction solution was incubated for $15 \mathrm{~min}$ at $100^{\circ} \mathrm{C}$ followed by cooling down to ambient temperature. The absorbance was detected under 450, 532 and $600 \mathrm{~nm}$ using an Ultrospec 2100 pro UV/Visible spectrophotometer (GE Healthcare Life Science, Uppsala, Sweden). The MDA content was calculated according to Li et al. [74].

For the REL determination, $0.2 \mathrm{~g}$ fresh leaves were cut and completely immersed in $20 \mathrm{~mL}$ deionized water, then degassed for $10 \mathrm{~min}$. The electrical conductivity of the solution (E1) was measured using a conductivity instrument (DDS-11A) after $20 \mathrm{~min}$. Subsequently, the solution was incubated at $100^{\circ} \mathrm{C}$ for $15 \mathrm{~min}$ and cooled to room temperature, and then the electrical conductivity of the solution (E2) was 
determined. In addition, the electrical conductivity of deionized water (E0) was also detected. The REL was calculated according to the equation: REL $(\%)=(\mathrm{E} 1-\mathrm{E} 0) /(\mathrm{E} 2-\mathrm{E} 0) \times 100 \%$.

Contents of proline and total soluble sugar were determined using ninhydrin reaction and an anthrone reagent method developed by Li et al. [74]. For the proline determination, $0.2 \mathrm{~g}$ fresh leaves were ground in $3 \mathrm{~mL} 3 \%(w / v)$ sulfosalicylic acid. After incubation at $100{ }^{\circ} \mathrm{C}$ for an hour and followed by cooling down to ambient temperature, the homogenate was centrifuged at $15,000 \times g$ for $10 \mathrm{~min}$ at $25{ }^{\circ} \mathrm{C}$. Then, $1 \mathrm{~mL}$ supernatant, $2 \mathrm{~mL}$ glacial acetic acid, and $2 \mathrm{~mL}$ ninhydrin were incubated at $100{ }^{\circ} \mathrm{C}$ for an hour. After cooled to room temperature, the incubated solution with addition of $8 \mathrm{~mL}$ methylbenzene was allowed to stand for an hour before the detection at $520 \mathrm{~nm}$ using a spectrophotometer.

For the total soluble sugar assay, $0.2 \mathrm{~g}$ fresh leaves were ground in $5 \mathrm{~mL}$ deionized water. The homogenate was incubated at $100{ }^{\circ} \mathrm{C}$ for $30 \mathrm{~min}$ followed by cooling down to ambient temperature. After centrifugation at $15,000 \times g$ for $10 \mathrm{~min}$ at $25^{\circ} \mathrm{C}$, the supernatant was collected and diluted with deionized water to $50 \mathrm{~mL}$. Then, $1 \mathrm{~mL}$ the extracting solution, $0.5 \mathrm{~mL} 2 \%(w / v)$ ethyl acetate solution of anthrone, and $5 \mathrm{~mL}$ concentrated sulfuric acid were incubated at $100{ }^{\circ} \mathrm{C}$ for $2 \mathrm{~min}$. The absorbance was detected under $630 \mathrm{~nm}$ using a spectrophotometer after cooled down to room temperature.

Glycine betaine content was measured using reinecke salt method as described by Zhao et al. [75]. Fresh leaves $(0.2 \mathrm{~g})$ were ground in liquid nitrogen, and then the powder was incubated for $24 \mathrm{~h}$ in $6 \mathrm{~mL} 0.375 \%(w / v)$ reinecke salt solution. The homogenate was centrifuged at $10,000 \times g$ for $15 \mathrm{~min}$ at $20{ }^{\circ} \mathrm{C}$. The supernatant was collected and filtered through a $0.45-\mu \mathrm{m}$-pore-size cellulose acetate filter. The filtrate was dried at $70{ }^{\circ} \mathrm{C}$ and then resuspended in $5 \mathrm{~mL}$ deionized water. After $5 \mathrm{~mL}$ reinecke salt solution was added, the reaction solution was incubated at $4{ }^{\circ} \mathrm{C}$ for $2 \mathrm{~h}$, and then centrifuged at $4000 \times g$ for $15 \mathrm{~min}$ at $4{ }^{\circ} \mathrm{C}$. The precipitate was collected, and then redissolved in $15 \mathrm{~mL}$ aether. Then, the solution was centrifuged at $4000 \times g$ for $15 \mathrm{~min}$ at $4{ }^{\circ} \mathrm{C}$. The supernatant was harvested, dried, and redissolved in $70 \%$ acetone. The absorbance was determined at $525 \mathrm{~nm}$ using a spectrophotometer. The contents of proline, total soluble sugar, and glycine betaine content were calculated from the standard curve.

\subsection{Determination of ROS and Antioxidant Substances Contents, and Antioxidant Enzyme Activity Assay}

The content of $\mathrm{H}_{2} \mathrm{O}_{2}$ was determined using potassium iodide reaction as described in Suo et al. [76]. Generation rate of $\mathrm{O}_{2}{ }^{\bullet-}$ was obtained according to a method of Zhao et al. [75]. For antioxidant enzyme activity assay, $0.2 \mathrm{~g}$ leaves were homogenized on ice in $3 \mathrm{~mL} 50 \mathrm{mM}$ phosphate buffer ( $\mathrm{pH} 7.8$, and containing $2 \%$ PVP-40 and $2 \mathrm{mM}$ ascorbate). After centrifugation at 15,000 $\times \mathrm{g}$ for $20 \mathrm{~min}$ at $4{ }^{\circ} \mathrm{C}$, the supernatant was collected for enzyme activity assays, including SOD, CAT, APX, GPX, POD, MDHAR, DHAR, GR, and GST. The activities of SOD, CAT, APX, POD, GR, and GST were assayed according to our previous methods [72]. The activities of GPX, MDHAR, and DHAR were measured according to our previous methods described by Suo et al. [76]. For all the enzyme activity assays, protein content was determined using the Bradford method [77]. In addition, contents of AsA, DHA, GSH, and GSSG were measured according to methods of Wei et al. [78].

\subsection{Protein Sample Preparation, 2DE, and Protein Abundance Analysis}

The proteins from leaves under different concentrations of $\mathrm{H}_{2} \mathrm{O}_{2}$ treatments were extracted using a phenol extraction method according to Wang et al. [73]. About $1.6 \mathrm{mg}$ protein was loaded on per gel, separated on linear gradient IPG strips $(24 \mathrm{~cm}, \mathrm{pH} 4-7)$ through isoelectric focusing (IEF) in the first dimension, followed by $12.5 \%$ SDS-PAGE gels in the second dimension, and stained by CBB staining. Gel image acquisition and analysis were conducted as described in detail in Wang et al. [73]. For quantitative analysis, the volume of each spot was normalized against the total valid spots. The protein spots displaying consistent abundance changes from three biological replicates with greater than 1.5-fold changes and a $p$ value smaller than 0.05 were considered to be DAP [72]. 


\subsection{Protein Identification by MALDI-TOF/TOF MS and Database Searching}

The DAP spots were excised from the gels and digested with trypsin as previously described [73]. MS/MS spectra were obtained using an ABI 5800 MALDI TOF/TOF MS (AB Sciex, Foster City, CA, USA). The mass error was below $30 \mathrm{ppm}$ at both MS and MS/MS mode, and the resolution was 10,000. The MS/MS spectra were subjected to the online Mascot program [79] to search against all green plants (Viridiplantae) in NCBInr protein databases [80]. The searching parameters were set according to Wang et al. [73], the mass accuracy was $0.3 \mathrm{Da}$, and the maximum number of missed cleavages was set to one. To obtain high confident identification, proteins had to meet the following criteria: (1) the top hits on the database searching report; (2) a probability-based MOWSE score greater than $52(p<0.05)$; and (3) more than two peptides matched with nearly complete y-ion series and complementary b-ion series.

\subsection{Protein Classification, Subcellular Localization, Hierarchical Cluster Analysis, and Protein-Protein Interaction Prediction}

The identified proteins were searched against the NCBI database [80] and UniProt database [81] to determine if their functions were known. Combined with knowledge from BLAST alignments and literature, proteins were classified into different categories.

The subcellular localization of the identified proteins were predicted using five Internet tools according to Suo et al. [76]: YLoc [82], LocTree3 [83], Plant-mPLoc [84], ngLOC [85], and TargetP [86]. Only the consistent predictions meeting the high criteria from at least two tools were accepted as a confident result.

Self-organizing tree algorithm hierarchical clustering of the protein abundance profiles was obtained from log (base 2) transformed fold change values of protein spots using Cluster software (version 3.0).

The protein-protein interactions were predicted using the web tool STRING 10 [30]. The homologs of the DAPs in Arabidopsis were obtained by sequence BLAST in TAIR database [31], and then the homologs were subjected to the web tool of STRING 10 for creating functional protein association networks, based on published literature, genome analysis of domain fusion, gene neighborhood, phylogenetic profiling/homology, co-expression, co-occurrence, and other experimental evidence [76].

\subsection{Statistical Analysis}

All the physiological results were presented as means \pm standard deviation (SD) of at least three biological replicates. Data were analyzed by one-way ANOVA followed by Duncan's test using the statistical software SPSS 17.0 (SPSS Inc., Chicago, IL, USA). A $p$ value smaller than 0.05 was considered to be statistically significant.

\section{Conclusion}

In the course of poplar development and stress-response in poplars, the molecular regulation of $\mathrm{H}_{2} \mathrm{O}_{2}$ homeostasis in the cells is complicated and fine-tuned. In the present study, we present a primary $\mathrm{H}_{2} \mathrm{O}_{2}$-responsive network in leaves of poplar $(P$. simonii $\times P$. nigra) using integrative analysis of physiological and proteomic approaches. The molecular network includes 14-3-3 protein-/NDPK-mediated signaling pathway, dynamics of thylakoid membrane structure, enhancement of diverse antioxidative defense system, alteration of photosynthesis, adjustment of carbohydrate and other basic metabolisms, as well as modulation of protein synthesis and conformation (Figure 9). This study provides new information and insights into underlying $\mathrm{H}_{2} \mathrm{O}_{2}$-responsive mechanisms in poplar plants. Although our proteomics results highlighted some critical candidate proteins/genes in $\mathrm{H}_{2} \mathrm{O}_{2}$-responsive signaling and metabolic pathways, their biological functions for $\mathrm{H}_{2} \mathrm{O}_{2}$ response in poplar still need future characterization using molecular genetics and PTM analysis tools. 
Supplementary Materials: Supplementary materials can be found at www.mdpi.com/1422-0067/18/10/2085/s1.

Acknowledgments: The project was supported by grants from the Fundamental Research Funds for the Central Universities (No. 2572016AA16 and No. 2572017ET01) to Juanjuan Yu, and Shaojun Dai, and Capacity Construction Project of Local Universities, Shanghai, China (No. 14390502700) to Shaojun Dai.

Author Contributions: Shaojun Dai conceived and designed the experiments; Juanjuan Yu, Xin Jin, Tianxiang Gao, Xiaomei Sun, and Xiaomei Chen performed the experiments; Yimin She and Tingbo Jiang contributed analysis tools and plant materials; and Juanjuan Yu and Xin Jin analyzed the data and wrote the manuscript with suggestions by Shaojun Dai and Sixue Chen. All authors have read and approved the final manuscript.

Conflicts of Interest: The authors declare no conflict of interest.

\section{Abbreviations}

14-3-3 B

2DE

${ }^{1} \mathrm{O}_{2}$

A3GT 2

$\mathrm{ADH}$

AKR

ALAD1

ALT

APX

AsA

BLAST

CA1

$\mathrm{CAB}$

CAT

cATP synthase $\alpha$

CBB

$\mathrm{Ci}$

cpHSP70

CYP26-2

DAP

DHA

DHAR

DnaK

EF-G2

ESTs

FBA

FNR

GAPDH2

GAPDH-A

Gly I

GPX

GR

GS

Gs

GSH

GSSG

GST

GST-F1

GST-U30

$\mathrm{H}_{2} \mathrm{O}_{2}$

$\mathrm{HAD}$

$\mathrm{HO}^{\bullet}$

HSC 80 14-3-3-like protein B

Two-dimensional gel electrophoresis

Singlet oxygen

Anthocyanidin 3-O-glucosyltransferase 2

Alcohol dehydrogenase

Aldo/keto reductase family protein

Delta-aminolevulinic acid dehydratase 1

Alanine aminotransferase family protein

Ascorbate peroxidase

Ascorbate

Basic local alignment search tool

Carbonic anhydrase isoform 1

Chlorophyll A/B binding protein

Catalase

ATP synthase CF1 $\alpha$ subunit

Coomassie brilliant blue

Intercellular $\mathrm{CO} 2$ concentration

Stromal $70 \mathrm{kda}$ heat shock-related family protein

Peptidyl-prolyl cis-trans isomerase CYP26-2

Differentially accumulated protein

Dehydroascorbate

Dehydroascorbate reductase

Chaperone Dnak

Elongation factor G-2

Expressed sequence tags

Fructose-bisphosphate aldolase

Ferredoxin-NADP reductase

Glyceraldehyde-3-phosphate dehydrogenase 2

Glyceraldehyde-3-phosphate dehydrogenase A

Glyoxalase I homolog family protein

Glutathione peroxidase

Glutathione reductase

Glutamine synthetase

Stomatal conductance

Reduced glutathione

Oxidized glutathione

Glutathione S-transferase

Glutathione S-transferase F1 (GST-F1)

Glutathione S-transferase U30

Hydrogen peroxide

Haloacid dehalogenase-like hydrolase family protein

Hydroxyl radicals

Heat shock cognate protein 80 


\begin{tabular}{|c|c|}
\hline HSP90 & Heat shock protein 90 \\
\hline IFR & Isoflavone reductase family protein \\
\hline IPG & Immobilized $\mathrm{pH}$ gradient \\
\hline IPMDH & 3-isopropyl malate dehydrogenase \\
\hline iTRAQ & Isobaric tags for relative and absolute quantification \\
\hline mATP synthase $d$ & ATP synthase subunit d \\
\hline mATP synthase $\beta$ & ATP synthase subunit beta \\
\hline MDA & Malondialdehyde \\
\hline MDHAR & Monodehydroascorbate reductase \\
\hline MFOR & 2-methylene-furan-3-one reductase \\
\hline MALDI & Matrix-assisted laser desorption/ ionization \\
\hline MS & Mass spectrometry \\
\hline NAD-MDH & NAD-dependent malate dehydrogenase \\
\hline $\mathrm{NADH}$ & Nicotinamide adenine dinucleotide \\
\hline NADPH & Nicotinamide adenine dinucleotide phosphate \\
\hline NDPK1 & Nucleoside diphosphate kinase 1 \\
\hline $\mathrm{O}_{2}^{\bullet-}$ & Superoxide anion radicals \\
\hline OAS-TL & O-acetylserine (thiol) lyase family protein \\
\hline OEC2 & Photosystem II oxygen-evolving complex protein 2 precursor \\
\hline PAP6 & Plastid-lipid-associated protein 6 \\
\hline PDH E1- $\beta$ & Pyruvate dehydrogenase E1 component subunit beta \\
\hline PGK1 & Phosphoglycerate Kinase 1 \\
\hline PGM & Phosphoglucomutase \\
\hline Pn & Net photosynthetic rate \\
\hline PnsL5 & Photosynthetic NDH subunit of lumenal location 5 \\
\hline POD & Peroxidase \\
\hline Pop3 & Pop3 peptide family protein \\
\hline PRK & Phosphoribulokinase \\
\hline PTM & post-translational modification \\
\hline RBCL & Rubisco large chain \\
\hline RBCS & Rubisco small chain \\
\hline $\mathrm{RBP}-\alpha$ & Rubisco large subunit-binding protein subunit $\alpha$ \\
\hline RCA & Rubisco activase \\
\hline REL & Relative electrolyte leakage \\
\hline ROS & Reactive oxygen species \\
\hline RuBisCO & Ribulose-bisphosphate carboxylase \\
\hline SBPase & Sedoheptulose-1, 7-bisphosphatase \\
\hline SOD & Superoxide dismutase \\
\hline SRB & Stress responsive A/B Barrel domain \\
\hline SRC2 & Soybean genes regulated by cold 2 (SRC2)-like domain \\
\hline TCA & Tricarboxylic acid \\
\hline TK & Transketolase \\
\hline TOF & Time of flight \\
\hline $\operatorname{Tr}$ & Transpiration rate \\
\hline Tubulin $\alpha$ & Tubulin $\alpha$ chain \\
\hline UROD & Uroporphyrinogen decarboxylase \\
\hline
\end{tabular}

\section{References}

1. Mittler, R.; Vanderauwera, S.; Gollery, M.; Van, B.F. Reactive oxygen gene network of plants. Trends Plant Sci. 2004, 9, 490-498. [CrossRef] [PubMed]

2. Mittler, R. ROS are good. Trends Plant Sci. 2017, 22, 11-19. [CrossRef] [PubMed]

3. Petrov, V.D.; van Breusegem, F. Hydrogen peroxide-A central hub for information flow in plant cells. AoB Plants 2012, 2012. [CrossRef] [PubMed] 
4. Rinalducci, S.; Murgiano, L.; Zolla, L. Redox proteomics: basic principles and future perspectives for the detection of protein oxidation in plants. J. Exp. Bot. 2008, 59, 3781-3801. [CrossRef] [PubMed]

5. Ishibashi, Y.; Yamamoto, K.; Tawaratsumida, T.; Yuasa, T.; Iwaya-Inoue, M. Hydrogen peroxide scavenging regulates germination ability during wheat (Triticum aestivum L.) seed maturation. Plant Sign. Behav. 2008, 3, 183-188. [CrossRef]

6. Uchida, A.; Jagendorf, A.T.; Hibino, T.; Takabe, T.; Takabe, T. Effects of hydrogen peroxide and nitric oxide on both salt and heat stress tolerance in rice. Plant Sci. 2002, 163, 515-523. [CrossRef]

7. Rokebul Anower, M.; Peel, M.D.; Mott, I.W.; Wu, Y. Physiological processes associated with salinity tolerance in an alfalfa half-sib family. J. Agro. Crop Sci. 2017. [CrossRef]

8. Liu, Z.J.; Guo, Y.K.; Bai, J.G. Exogenous hydrogen peroxide changes antioxidant enzyme activity and protects ultrastructure in leaves of two cucumber ecotypes under osmotic stress. J. Plant Growth Regul. 2010, 29, 171-183. [CrossRef]

9. Xu, F.J.; Jin, C.W.; Liu, W.J.; Zhang, Y.S.; Lin, X.Y. Pretreatment with $\mathrm{H}_{2} \mathrm{O}_{2}$ alleviates aluminum-induced oxidative stress in wheat seedlings. J. Integr. Plant Biol. 2011, 53, 44-53. [CrossRef] [PubMed]

10. Kumar, M.; Sirhindi, G.; Bhardwaj, R.; Kumar, S.; Jain, G. Effect of exogenous $\mathrm{H}_{2} \mathrm{O}_{2}$ on antioxidant enzymes of Brassica juncea L. seedlings in relation to 24-epibrassinolide under chilling stress. Indian J. Biochem. Biophys. 2010, 47, 378-382. [PubMed]

11. Moskova, I.; Todorova, D.; Alexieva, V.; Segiev, I. Protective effect of hydrogen peroxide against paraquat toxicity in young pea plants: Possible role of endogenous polyamines. Am. J. Plant Sci. 2014, 5, 3408-3416. [CrossRef]

12. Bădărău, C.L.; Chiru, N.; Damsa, F.; Nistor, A. Effects of Satureja hortensis oil treatments and exogenous $\mathrm{H}_{2} \mathrm{O}_{2}$ on Potato virus Y (PVY) infected Solanum tuberosum L. plants under drought conditions. An. Univers. Orad. Fasc. Biol. 2012, 19, 140-145.

13. Desikan, R.; A-H-Mackerness, S.; Hancock, J.T.; Neill, S.J. Regulation of the Arabidopsis transcriptome by oxidative stress. Plant Physiol. 2001, 127, 159-172. [CrossRef] [PubMed]

14. Vandenabeele, S.; van der Kelen, K.; Dat, J.; Gadjev, I.; Boonefaes, T.; Morsa, S.; Rottiers, P.; Slooten, L.; van Montagu, M.; Zabeau, M.; et al. A comprehensive analysis of hydrogen peroxide-induced gene expression in tobacco. Proc. Natl. Acad. Sci. USA 2003, 100, 16113-16118. [CrossRef] [PubMed]

15. Vanderauwera, S.; Zimmermann, P.; Rombauts, S.; Vandenabeele, S.; Langebartels, C.; Gruissem, W.; Inze, D.; van Breusegem, F. Genome-wide analysis of hydrogen peroxide-regulated gene expression in Arabidopsis reveals a high light-induced transcriptional cluster involved in anthocyanin biosynthesis. Plant Physiol. 2005, 139, 806-821. [CrossRef] [PubMed]

16. Li, A.L.; Zhang, R.Z.; Pan, L.; Tang, L.C.; Zhao, G.G.; Zhu, M.Z.; Chu, J.F.; Sun, X.H.; Wei, B.; Zhang, X.Q.; et al. Transcriptome analysis of $\mathrm{H}_{2} \mathrm{O}_{2}$-treated wheat seedlings reveals a $\mathrm{H}_{2} \mathrm{O}_{2}$-responsive fatty acid desaturase gene participating in powdery mildew resistance. PLOS ONE 2011, 6, e28810. [CrossRef] [PubMed]

17. Wan, X.Y.; Liu, J.Y. Comparative proteomics analysis reveals an intimate protein network provoked by hydrogen peroxide stress in rice seedling leaves. Mol. Cell. Proteom. 2008, 7, 1469-1488. [CrossRef] [PubMed]

18. Tanou, G.; Job, C.; Belghazi, M.; Molassiotis, A.; Diamantidis, G.; Job, D. Proteomic signatures uncover hydrogen peroxide and nitric oxide cross-talk signaling network in citrus plants. J. Proteome Res. 2010, 9, 5994-6006. [CrossRef] [PubMed]

19. Bian, Y.W.; Lv, D.W.; Cheng, Z.W.; Gu, A.Q.; Cao, H.; Yan, Y.M. Integrative proteome analysis of Brachypodium distachyon roots and leaves reveals a synergetic responsive network under $\mathrm{H}_{2} \mathrm{O}_{2}$ stress. J. Proteom. 2015, 128, 388-402. [CrossRef] [PubMed]

20. Ge, P.; Hao, P.; Cao, M.; Guo, G.; Lv, D.; Subburaj, S.; Li, X.; Yan, X.; Xiao, J.; Ma, W.; et al. iTRAQ-based quantitative proteomic analysis reveals new metabolic pathways of wheat seedling growth under hydrogen peroxide stress. Proteomics 2013, 13, 3046-3058. [CrossRef] [PubMed]

21. Tuskan, G.A.; Difazio, S.; Jansson, S.; Bohlmann, J.; Grigoriev, I.; Hellsten, U.; Putnam, N.; Ralph, S.; Rombauts, S.; Salamov, A.; et al. The genome of black cottonwood, Populus trichocarpa (Torr. \& Gray). Science 2006, 313, 1596-1604. [CrossRef] [PubMed]

22. Ren, H.Q.; Liu, X.; Jiang, Z.H.; Wang, Y.h.; Yu, H.Q. Effects of planting density on wood anatomical properties of Populus $\times$ xiaohei. For. Res. 2006, 19, 364-369. 
23. Gao, W.; Bai, S.; Li, Q.; Gao, C.; Liu, G.; Li, G.; Tan, F. Overexpression of TaLEA gene from Tamarix androssowii improves salt and drought tolerance in transgenic poplar (Populus simonii $\times$ P. nigra). PLoS ONE 2013, 8, e67462. [CrossRef] [PubMed]

24. Cao, C.W.; Liu, G.F.; Wang, Z.Y.; Yan, S.C.; Ma, L.; Yang, C.P. Response of the gypsy moth, Lymantria dispar to transgenic poplar, Populus simonii $\times$ P. nigra, expressing fusion protein gene of the spider insecticidal peptide and Bt-toxin C-peptide. J. Insect Sci. 2010, 10, 1-13. [CrossRef]

25. Wang, Z.B. Study on poplar transgene of the fungus disease-resistance. Forest. Sci. Tech. 2006, 31, 22-24.

26. Wang, L.; Zhou, B.; Wu, L.L.; Guo, B.Z.; Jiang, T.B. Differentially expressed genes in Populus simonii $\times$ Populus nigra in response to $\mathrm{NaCl}$ stress using cDNA-AFLP. Plant Sci. 2011, 180, 796-801. [CrossRef] [PubMed]

27. Chen, S.; Jiang, J.; Li, H.; Liu, G. The salt-responsive transcriptome of Populus simonii $\times$ Populus nigra via DGE. Gene 2012, 504, 203-212. [CrossRef] [PubMed]

28. Yuan, H.M.; Chen, S.; Lin, L.; Wei, R.; Li, H.Y.; Liu, G.F.; Jiang, J. Genome-wide analysis of a TaLEA-introduced transgenic Populus simonii $\times$ Populus nigra dwarf mutant. Int. J. Mol. Sci. 2012, 13, 2744-2762. [CrossRef] [PubMed]

29. Chen, S.; Yuan, H.M.; Liu, G.F.; Li, H.Y.; Jiang, J. A label-free differential quantitative proteomics analysis of a TaLEA-introduced transgenic Populus simonii $\times$ Populus nigra dwarf mutant. Mol. Biol. Rep. 2012, 39, 7657-7664. [CrossRef] [PubMed]

30. STRING: Functional Protein Association Networks. Available online: http://string-db.org (accessed on 2 April 2017).

31. TAIR BLAST 2.2.8. Available online: http://www.arabidopsis.org/Blast/index.jsp (accessed on 2 April 2017).

32. Chang, I.F.; Curran, A.; Woolsey, R.; Quilici, D.; Cushman, J.C.; Mittler, R.; Harmon, A.; Harper, J.F. Proteomic profiling of tandem affinity purified 14-3-3 protein complexes in Arabidopsis thaliana. Proteomics 2009, 9, 2967-2985. [CrossRef] [PubMed]

33. Roberts, M.R.; Salinas, J.; Collinge, D.B. 14-3-3 proteins and the response to abiotic and biotic stress. Plant Mol. Biol. 2002, 50, 1031-1039. [CrossRef] [PubMed]

34. Moon, H.; Lee, B.; Choi, G.; Shin, D.; Prasad, D.T.; Lee, O.; Kwak, S.S.; Kim, D.H.; Nam, J.; Bahk, J.; et al. NDP kinase 2 interacts with two oxidative stress-activated MAPKs to regulate cellular redox state and enhances multiple stress tolerance in transgenic plants. Proc. Natl. Acad. Sci. USA 2003, 100, 358-363. [CrossRef] [PubMed]

35. Dorion, S.; Rivoal, J. Clues to the functions of plant NDPK isoforms. Naunyn-Schmiedeberg's Arch. Pharmacol. 2015, 388, 119-132. [CrossRef] [PubMed]

36. Leitnerdagan, Y.; Ovadis, M.; Shklarman, E.; Elad, Y.; Rav, D.D.; Vainstein, A. Expression and functional analyses of the plastid lipid-associated protein CHRC suggest its role in chromoplastogenesis and stress. Plant Physiol. 2006, 142, 233-244. [CrossRef] [PubMed]

37. Gillet, B.; Beyly, A.; Peltier, G.; Rey, P. Molecular characterization of CDSP 34, a chloroplastic protein induced by water deficit in Solanum tuberosum L. plants, and regulation of CDSP 34 expression by ABA and high illumination. Plant J. 1998, 16, 257-262. [CrossRef] [PubMed]

38. Kim, H.U.; Wu, S.S.; Ratnayake, C.; Huang, A.H. Brassica rapa has three genes that encode proteins associated with different neutral lipids in plastids of specific tissues. Plant Physiol. 2001, 126, 330-341. [CrossRef] [PubMed]

39. Laizet, Y.; Pontier, D.; Mache, R.; Kuntz, M. Subfamily organization and phylogenetic origin of genes encoding plastid lipid-associated proteins of the fibrillin type. J. Genome Technol. Sci. 2004, 3, 19-28. [CrossRef]

40. Bartolo, M.E.; Carter, J.V. Microtubules in mesophyll cells of nonacclimated and cold-acclimated spinach: Visualization and responses to freezing, low temperature, and dehydration. Plant Physiol. 1991, 97, 175-181. [CrossRef] [PubMed]

41. Abdrakhamanova, A.; Wang, Q.Y.; Khokhlova, L.; Nick, P. Is microtubule disassembly a trigger for cold acclimation? Plant Cell Physiol. 2003, 44, 676-686. [CrossRef] [PubMed]

42. Shoji, T.; Suzuki, K.; Abe, T.; Kaneko, Y.; Shi, H.; Zhu, J.K.; Rus, A.; Hasegawa, P.M.; Hashimoto, T. Salt stress affects cortical microtubule organization and helical growth in Arabidopsis. Plant Cell Physiol. 2006, 47, 1158-1168. [CrossRef] [PubMed]

43. Ban, Y.; Kobayashi, Y.; Hara, T.; Hamada, T.; Hashimoto, T.; Takeda, S.; Hattori, T. $\alpha$-Tubulin is rapidly phosphorylated in response to hyperosmotic stress in rice and Arabidopsis. Plant Cell Physiol. 2013, 54, 848-858. [CrossRef] [PubMed] 
44. Jiang, J.L. Effects of $\mathrm{H}_{2} \mathrm{O}_{2}$ stress on physiological and biochemical index of Grass Pea. Acta Agr. Boreali-Occident. Sin. 2015, 25, 243-248. [CrossRef]

45. Yoshimura, K.; Miyao, K.; Gaber, A.; Takeda, T.; Kanaboshi, H.; Miyasaka, H.; Shigeoka, S. Enhancement of stress tolerance in transgenic tobacco plants overexpressing Chlamydomonas glutathione peroxidase in chloroplasts or cytosol. Plant J. 2004, 37, 21-33. [CrossRef] [PubMed]

46. Sytykiewicz, H. Expression patterns of genes involved in ascorbate-glutathione cycle in aphid-infested maize (Zea mays L.) seedlings. Int. J. Mol. Sci. 2016, 17, 268. [CrossRef] [PubMed]

47. Mohsenzadeh, S.; Esmaeili, M.; Moosavi, F.; Shahrtash, M.; Saffari, B.; Mohabatkar, H. Plant glutathione S-transferase classification, structure and evolution. Afr. J. Biotechnol. 2011, 10, 8160-8165.

48. Kaur, C.; Singlapareek, S.L.; Sopory, S.K. Glyoxalase and methylglyoxal as biomarkers for plant stress tolerance. Crit. Rev. Plant Sci. 2014, 33, 429-456. [CrossRef]

49. Sengupta, D.; Naik, D.; Reddy, A.R. Plant aldo-keto reductases (AKRs) as multi-tasking soldiers involved in diverse plant metabolic processes and stress defense: A structure-function update. J. Plant Physiol. 2015, 179, 40-55. [CrossRef] [PubMed]

50. Liu, P.; Zhang, H.; Wang, H.; Xia, Y. Identification of redox-sensitive cysteines in the Arabidopsis proteome using OxiTRAQ, a quantitative redox proteomics method. Proteomics 2014, 14, 750-762. [CrossRef] [PubMed]

51. Hu, Q.; Guo, G.; Yang, Z.; Li, Y.; Xia, Y.; Li, N. Stable isotope metabolic labeling-based quantitative thiol redox proteomic analysis of hydrogen peroxide-treated Arabidopsis plant. J. Proteom. Bioinformat. 2014, 7 , 121-133. [CrossRef]

52. Muthuramalingam, M.; Matros, A.; Scheibe, R.; Mock, H.P.; Dietz, K.J. The hydrogen peroxide-sensitive proteome of the chloroplast in vitro and in vivo. Front. Plant Sci. 2013, 4, 54. [CrossRef] [PubMed]

53. Wang, H.; Wang, S.; Lu, Y.; Alvarez, S.; Hicks, L.M.; Ge, X.; Xia, Y. Proteomic analysis of early-responsive redox-sensitive proteins in Arabidopsis. J. Proteome Res. 2012, 11, 412-424. [CrossRef] [PubMed]

54. Regier, N.; Streb, S.; Cocozza, C.; Schaub, M.; Cherubini, P.; Zeeman, S.C.; Frey, B. Drought tolerance of two black poplar (Populus nigra L.) clones: Contribution of carbohydrates and oxidative stress defence. Plant Cell Environ. 2009, 32, 1724-1736. [CrossRef] [PubMed]

55. Ellis, M.H.; Dennis, E.S.; Peacock, W.J. Arabidopsis roots and shoots have different mechanisms for hypoxic stress tolerance. Plant Physiol. 1999, 119, 57-64. [CrossRef] [PubMed]

56. Musrati, R.A.; Kollárová, M.; Mernik, N.; Mikulásová, D. Malate dehydrogenase: Distribution, function and properties. Gen. Physiol. Biophys. 1998, 17, 193-210. [PubMed]

57. Tischner, R. Nitrate uptake and reduction in higher and lower plants. Plant Cell Environ. 2000, 23, $1005-1024$. [CrossRef]

58. Zagorchev, L.; Seal, C.E.; Kranner, I.; Odjakova, M. A central role for thiols in plant tolerance to abiotic stress. Int. J. Mol. Sci. 2013, 14, 7405-7432. [CrossRef] [PubMed]

59. Pereira, L.B.; Tabaldi, L.A.; Gonçalves, J.F.; Jucoski, G.O.; Pauletto, M.M.; Weis, S.N.; Nicoloso, F.T.; Borher, D.; Rocha, J.B.T.; Schetinger, M.R.C. Effect of aluminum on $\delta$-aminolevulinic acid dehydratase (ALA-D) and the development of cucumber (Cucumis sativus). Environ. Exp. Bot. 2006, 57, 106-115. [CrossRef]

60. Skrebsky, E.C.; Tabaldi, L.A.; Pereira, L.B.; Rauber, R.; Maldaner, J.; Cargnelutti, D.; Gonçalves, J.F.; Castro, G.Y.; Shetinger, M.R.; Nicoloso, F.T. Effect of cadmium on growth, micronutrient concentration, and $\delta$-aminolevulinic acid dehydratase and acid phosphatase activities in plants of Pfaffia glomerata. Braz. J. Plant Physiol. 2008, 20, 285-294. [CrossRef]

61. Gupta, D.K.; Nicoloso, F.T.; Schetinger, M.R.; Rossato, L.V.; Pereira, L.B.; Castro, G.Y.; Srivastava, S.; Tripathi, R.D. Antioxidant defense mechanism in hydroponically grown Zea mays seedlings under moderate lead stress. J. Hazard. Mater. 2009, 172, 479-484. [CrossRef] [PubMed]

62. Mock, H.P.; Keetman, U.; Kruse, E.; Rank, B.; Grimm, B. Defense responses to tetrapyrrole-induced oxidative stress in transgenic plants with reduced uroporphyrinogen decarboxylase or coproporphyrinogen oxidase activity. Plant Physiol. 1998, 116, 107-116. [CrossRef]

63. Wang, W.X.; Vinocur, B.; Shoseyov, O.; Altman, A. Role of plant heat-shock proteins and molecular chaperones in the abiotic stress response. Trends Plant Sci. 2004, 9, 244-252. [CrossRef] [PubMed]

64. Demirevska, K.; Simova-Stoilova, L.; Vassileva, V.; Feller, U. Rubisco and some chaperone protein responses to water stress and rewatering at early seedling growth of drought sensitive and tolerant wheat varieties. Plant Growth Regul. 2008, 56, 97-106. [CrossRef] 
65. Caruso, G.; Cavaliere, C.; Guarino, C.; Gubbiotti, R.; Foglia, P.; Laganà, A. Identification of changes in Triticum durum L. leaf proteome in response to salt stress by two-dimensional electrophoresis and MALDI-TOF mass spectrometry. Anal. Bioanal. Chem. 2008, 391, 381-390. [CrossRef] [PubMed]

66. Salvucci, M.E. Association of Rubisco activase with chaperonin-60ß: A possible mechanism for protecting photosynthesis during heat stress. J. Exp. Bot. 2008, 59, 1923-1933. [CrossRef] [PubMed]

67. Yu, A.M.; Li, P.; Tang, T.; Wang, J.C.; Chen, Y.; Liu, L. Roles of Hsp70s in stress responses of microorganisms, plants, and animals. BioMed Res. Int. 2015, 2015, 510319. [CrossRef] [PubMed]

68. Schroda, M.; Vallon, O.; Wollman, F.-A.; Beck, C.F. A chloroplast-targeted heat shock protein 70 (HSP70) contributes to the photoprotection and repair of photosystem II during and after photoinhibition. Plant Cell 1999, 11, 1165-1178. [CrossRef] [PubMed]

69. Duan, Y.H.; Guo, J.; Ding, K.; Wang, S.J.; Zhang, H.; Dai, X.W.; Chen, Y.Y.; Govers, F.; Huang, L.L.; Kang, Z.S. Characterization of a wheat HSP70 gene and its expression in response to stripe rust infection and abiotic stresses. Mol. Biol. Rep. 2011, 38, 301-307. [CrossRef] [PubMed]

70. Nover, L.; Scharf, K.D. Synthesis, modification and structural binding of heat-shock proteins in tomato cell cultures. Eur. J. Biochem. 1984, 139, 303-313. [CrossRef] [PubMed]

71. Xu, Z.S.; Li, Z.Y.; Chen, Y.; Chen, M.; Li, L.C.; Ma, Y.Z. Heat shock protein 90 in plants: Molecular mechanisms and roles in stress responses. Int. J. Mol. Sci. 2012, 13, 15706-15723. [CrossRef] [PubMed]

72. Yu, J.; Chen, S.; Zhao, Q.; Wang, T.; Yang, C.; Diaz, C.; Sun, G.; Dai, S. Physiological and proteomic analysis of salinity tolerance in Puccinellia tenuiflora. J. Proteome Res. 2011, 10, 3852-3870. [CrossRef] [PubMed]

73. Wang, X.; Chen, S.; Zhang, H.; Shi, L.; Cao, F.; Guo, L.; Xie, Y.; Wang, T.; Yan, X.; Dai, S. Desiccation tolerance mechanism in resurrection fern-ally Selaginella tamariscina revealed by physiological and proteomic analysis. J. Proteome Res. 2010, 9, 6561-6577. [CrossRef] [PubMed]

74. Li, H.S.; Sun, Q.; Zhao, S.J.; Zhang, W.H. Principles and Techniques of Plant Physiological Biochemical Experiment; Higher Education Press: Beijing, China, 2000; pp. 186-191.

75. Zhao, Q.; Suo, J.; Chen, S.; Jin, Y.; Ma, X.; Yin, Z.; Zhang, Y.; Wang, T.; Luo, J.; Jin, W.; et al. $\mathrm{Na}_{2} \mathrm{CO}_{3}$-responsive mechanisms in halophyte Puccinellia tenuiflora roots revealed by physiological and proteomic analyses. Sci. Rep. 2016, 6, 32717. [CrossRef] [PubMed]

76. Suo, J.; Zhao, Q.; Zhang, Z.; Chen, S.; Cao, J.; Liu, G.; Wei, X.; Wang, T.; Yang, C.; Dai, S. Cytological and proteomic analyses of Osmunda cinnamomea germinating spores reveal characteristics of fern spore germination and rhizoid tip-growth. Mol. Cell. Proteom. 2015, 14, 2510. [CrossRef] [PubMed]

77. Bradford, M.M. A rapid and sensitive method for the quantitation of microgram quantities of protein utilizing the principle of protein-dye binding. Anal. Biochem. 1976, 72, 248-254. [CrossRef]

78. Wei, S.; Bian, Y.; Zhao, Q.; Chen, S.; Mao, J.; Song, C.; Cheng, K.; Xiao, Z.; Zhang, C.; Ma, W.; et al. Salinity-induced palmella formation mechanism in halotolerant algae Dunaliella salina revealed by quantitative proteomics and phosphoproteomics. Front. Plant Sci. 2017, 8, 810. [CrossRef] [PubMed]

79. Matrix Science. Available online: http:/ / www.matrixscience.com (accessed on 2 December 2016).

80. National Center for Biotechnology Information Non-Redundant (NCBInr) Protein Databases. Available online: http:/ / www.ncbi.nlm.nih.gov / protein/ (accessed on 2 December 2016).

81. UniProt. Available online: http:/ / www.uniprot.org/ (accessed on 15 March 2017).

82. YLoc: Interpretable Subcellular Localization Prediction. Available online: http:/ /abi.inf.uni-tuebingen.de/ Services/YLoc/webloc.cgi (accessed on 25 March 2017).

83. LocTree3: Protein Subcellular Localization Prediction System. Available online: https://rostlab.org/services / loctree3/ (accessed on 25 March 2017).

84. Plant-mPLoc: Predicting Subcellular Localization of Plant Proteins Including Those With Multiple Sites. Available online: http:/ / www.csbio.sjtu.edu.cn/bioinf/plant-multi/\# (accessed on 25 March 2017).

85. ngLOC: A Bayesian method for Predicting Protein Subcellular Localization. Available online: http://genome. unmc.edu/ngLOC/index.html (accessed on 25 March 2017).

86. TargetP 1.1 Server. Available online: http://www.cbs.dtu.dk/services/TargetP/ (accessed on 25 March 2017).

(C) 2017 by the authors. Licensee MDPI, Basel, Switzerland. This article is an open access article distributed under the terms and conditions of the Creative Commons Attribution (CC BY) license (http:/ / creativecommons.org/licenses/by/4.0/). 